\title{
Epibenthic communities of sedimentary habitats in a NE Atlantic deep seamount (Galicia Bank)
}

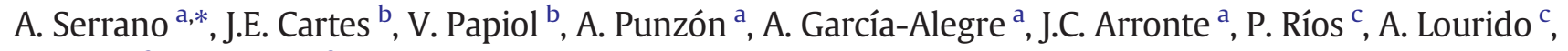 \\ I. Frutos ${ }^{a}$, M. Blanco ${ }^{a}$ \\ a Instituto Español de Oceanografía, Centro Oceanográfico de Santander, Spain \\ b Institut de Ciències del Mar de Barcelona, CSIC, Spain \\ c Instituto Español de Oceanografía, Centro Oceanográfico de Coruña, Spain
}

\section{A R T I C L E I N F O}

\section{Article history:}

Received 4 November 2016

Received in revised form 1 March 2017

Accepted 10 March 2017

Available online $\mathrm{xxxx}$

\section{Keywords:}

Deep sea

Seamount

Benthic communities

Vulnerable habitats

Marine protected areas

\begin{abstract}
A B S T R A C T
Galicia Bank is a deep seamount included as Site of Community Importance (SCI) in the Spanish Natura 2000 Network proposal. In the present study, epibenthic assemblages of sedimentary habitats have been described, together with the main environmental factor explaining species and communities distribution. Five epibenthic assemblages have been identified. Depth was the main factor explaining assemblage distribution, and the role of sediment type, water masses, and coral framework presence is also discussed. Three assemblages are located in the summit: the shallowest one (730-770 m), in the boundary between Eastern North Atlantic Central Water (ENACW) and Mediterranean Overflow Water (MOW) water masses is typified by ophiuroids and characterized by medium sands. The second assemblage (770-800 m) typified by the bivalve Limopsis minuta and the solitary coral Flabellum chunii correspond with medium sands and MOW core; and the third typified by the presence of cold-water coral communities dominated by Lophelia pertusa and Madrepora oculata, also on the MOW influence. In the border of the summit, in the bank break, an assemblage located in the range 1000-1200 $\mathrm{m}$ is dominated by the urchin Cidaris cidaris and the sponge Thenea muricata. In the flat flanks around the bank, the deepest assemblage (1400-1800 m) is dominated by the holothurian Benthogone rosea, in a depth range dominated by the Labrador water (LSW) and in fine sands with highest contents of organic matter. Most of species appeared in a depth range smaller than $25 \%$ of total depth range sampled and in $<10 \%$ of samples. Differential preference of species is evident in the different trophic guilds, with a higher dominance of filter-feeders in the summit and of deposit-feeders in the deepest assemblage, and have clear links with nutrient dynamics in the bank.
\end{abstract}

(C) 2017 Elsevier B.V. All rights reserved.

\section{Introduction}

Seamounts comprise a unique deep-sea environment, usually described as hotspots of biodiversity and refuges of vulnerable fauna. Their special environmental conditions generate singular ecosystem functioning. Seamounts interacting with oceanic currents create flow complexities which include substantially enhanced currents, eddy formation and local upwelling (Boehlert and Genin, 1987). Eddies may become trapped over the seamounts and form closed circulation cells called Taylor columns which may have important effects upon pelagic and benthic ecosystems over seamounts, specifically on nutrients dynamics. Topographic-induced nutrient retention and resuspension allow the presence of well-developed communities of vulnerable

\footnotetext{
* Corresponding author.

E-mail address: aserrano@st.ieo.es (A. Serrano).
}

filter-feeders (cold-water corals, sponges) and their accompanying fauna (Genin et al., 1986; Boehlert and Genin, 1987; Rogers, 1994; Flach et al., 2002; Tempera et al., 2012).

Deep seamount communities typically include slow-growing, longliving organisms that are sensitive to mechanical disturbance (Schlacher et al., 2013). This is one of the main reasons to consider seamounts as highly vulnerable, together with the wide range of pressures which can potentially affect them. As part of the necessary effort to preserve these deep-sea ecosystems, the Spanish government has named eleven off-shore areas as Sites of Community Importance (SCI) under the Habitat Directive (Council Directive 92/43/EEC). These areas were shortlisted based on previous knowledge and their priority features studied within the research project INDEMARES (EC contract LIFE 07/NAT/E/000732) and will become Special Areas of Conservation (SACs) upon the development of management plans and the agreement of the European Commission. The main objective of the project 
INDEMARES was to provide the necessary information to establish a network of representative Marine Protected Areas (MPAs) in Spanish waters.

Galicia Bank (GB) is the deepest SCI of the Spanish proposal. This area was considered relevant for research in the framework of the INDEMARES project because of the presence of well-developed and conserved priority habitats such as Lophelia and Madrepora communities and black and bamboo coral aggregations (Duineveld et al., 2004; Somoza et al., 2014), some of which are catalogued as vulnerable (OSPAR, 2008; Annex I Habitat Directive, 92/43/EEC). Most of the 800 major seamounts catalogued in the North Atlantic occur in high seas (Gubbay, 2003). GB is not that kind of seamount, showing several singularities due to its proximity to the continent, its deep summit (Surugiu et al., 2008) and its location on the confluence of water masses and currents (Cartes et al., 2014).

Seamounts provide a variety of environments resulting of a combination of sharp gradients of depth, slope, substrate type, water masses, currents, etc., which mirrors in the distribution of physical habitats and biotopes (i.a. Boehlert and Genin, 1987; Rogers, 1994; Tempera et al., 2012; Du Preez et al., 2016). Description of benthic biodiversity and habitat preference by deep-sea species is of great interest for the future monitoring on the effects of the GB SAC implementation. Such information is also important for the assessment of the Good Ecological Status in several indicators of the Marine Strategy Framework Directive (MSFD) concerning habitats conservation, among them, typical species composition, multimetric indices and physical damage of habitats.

In this study we identified epibenthic assemblages dwelling on sedimentary habitats of GB, determine which environmental variables act as key factors explaining communities distribution, and describe the differential use of those habitats by GB deep-sea epibenthic species.

\section{Material and methods}

\subsection{Study area}

GB is an isolated non-volcanic seamount (Black et al., 1964), located 120 nautical miles west of the NW Spanish shoreline (Fig. 1). The outline of its summit is almost triangular-shaped, being $75 \mathrm{~km}$ long in NNE-SSW direction, $58 \mathrm{~km}$ wide in WNW-ESE direction, and with a total surface of $1844 \mathrm{~km}^{2}$. Across its top surface, depths range from $600 \mathrm{~m}$ (to the SE) to $>2000 \mathrm{~m}$ (to the W), showing a bank break (significant increase in slope) at around 1000-1400 m. Depth strata 1200$2000 \mathrm{~m}$ (called in this paper bank flanks) is a transitional area between summit and bank break characterized by an slight increase in slope.

In the northeastern Atlantic, GB is considered a "coastal" seamount, together with the Ampere, Gorringe, Josephine and Seine banks, in

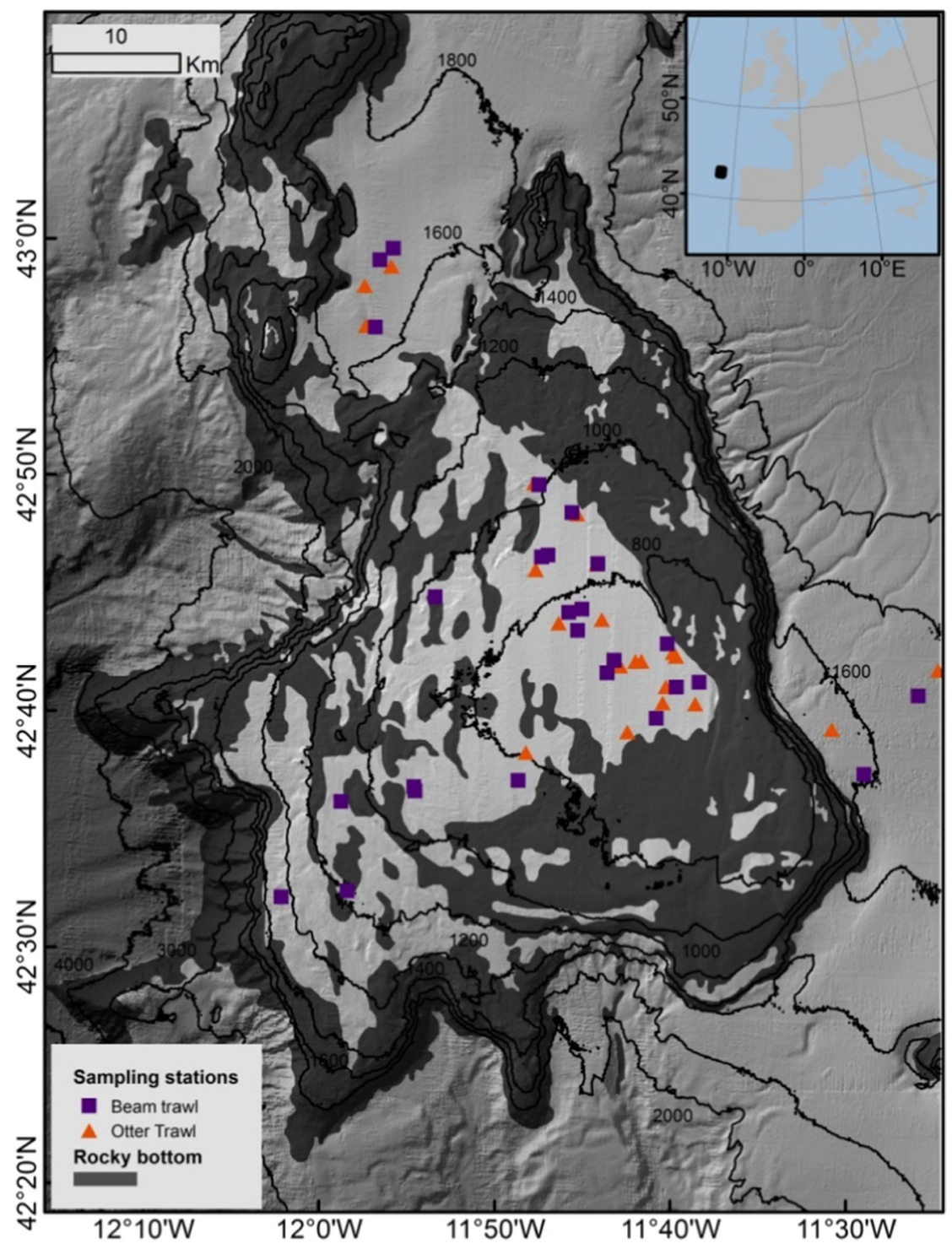

Fig. 1. Study area and sampling stations. Bathymetry from the Spanish EEZ Project (multibeam bathymetry). 
contrast with oceanic seamounts, including the Atlantis, Hyeres, Irving, Meteor and Plato banks located in high seas (Gofas, 2007; Surugiu et al., 2008). Nevertheless, some results on inter-seamount faunal similarity highlight the differentiation of GB due to its isolated northern position and deep plateau (Surugiu et al., 2008).

The great interest of GB is based on its location in the middle of main hydrographic drivers in the Atlantic Ocean. Surrounding GB, at depths sampled in this study (up to $1800 \mathrm{~m}$ ), there are 3 water masses direct/indirectly related with the communities sampled: i) Eastern North Atlantic Central Water (ENACW) occupies the level of hydrographic structures found over the GB summit; ii) below ENACW and to ca. $1500 \mathrm{~m}$, Mediterranean Outflow Water (MOW) characterized by an increase of salinity. MOW has a maximum core, with higher salinity and low-oxygen concentration at depths between $800 \mathrm{~m}$ and 1100-1200 m (Ambar and Howe, 1979; Iorga and Lozier, 1999; INDEMARES data). This water mass comes from the Strait of Gibraltar, and reaches velocities of $5-10 \mathrm{~cm} / \mathrm{s}$ (Iorga and Lozier, 1999), and iii) below MOW, Labrador Sea Water (LSW) that moves southwards from northern latitudes to GB and has a core at $1800 \mathrm{~m}$ (Iorga and Lozier, 1999).

Data from INDEMARES project show that sediments on the GB are mainly composed of sands with low organic content. In general, medium sands dominate the summit of the bank, and finer sediments (fine and very fine sands) prevail in the deepest areas (below $1300 \mathrm{~m}$ deep), mainly in the northern and southern part of the bank. The sorting coefficient varies from moderate to moderately good down to $1600 \mathrm{~m}$ depth, but the selection is poor or bad in the deeper stations (from $1700 \mathrm{~m}$ depth). The organic matter content is low, especially in medium sands of the summit (1-2\%), but also in the deeper fine and very fine sands (2-3.5\%).

\subsection{Biological samples}

Data was obtained in three multidisciplinary surveys performed on GB in summers of 2009, 2010 and 2011 (Ecomarg0709; BanGal0810; BanGal0811). Megaepibenthic fauna was collected with two different sampling gears, beam trawl and otter trawl (GOC73), in sedimentary grounds. Beam trawls are optimal gear for collecting small epibenthic invertebrates. This sampling gear consists of two steel skids joined by a $3.5 \mathrm{~m}$ horizontal bar with a vertical opening of $1 \mathrm{~m}$ and mesh size of $10 \mathrm{~mm}$. Trawling was carried out during $15 \mathrm{~min}$ at an average speed of 2 knots. The otter trawl used was a standardized GOC73 bottom trawl used in monitoring programs in the Mediterranean (Bertrand et al., 2002). It is a 2-warp trawl with two doors, $35.7 \mathrm{~m}$ headline length, $30 \mathrm{~m}$ bridles, a vertical height or opening of $2.7 \mathrm{~m}$ and $20 \mathrm{~mm}$ mesh at the codend. Haul duration was $45 \mathrm{~min}$ at $2.8-2.9$ knots. Trawl openings were recorded by means of SCANMAR and Simrad ITI Trawl monitoring sensors mounted in the mouths of the trawls.

Faunal data from both samplers is quantitative and expressed in biomass (wet weight). During the three surveys, a total of 22 otter trawls and 26 beam trawls were carried out across the sedimentary grounds of the seamount from 650 to $1800 \mathrm{~m}$ deep (Fig. 1).

Sediments were collected with a USNEL box corer (Hessler and Jumars, 1974), a standard quantitative sampler, at the same station where trawls were performed. Temperature $(T)$ and salinity $(S)$ in the water column were measured during each haul using a CTD Seabird SBE-911 (only near-bottom T and S were used).

\subsection{Epibenthic assemblages identification}

In order to describe epibenthic assemblages, data from otter trawl and beam trawl were analysed by means of multivariate analysis. Those analyses were performed firstly for beam trawl and otter trawl data separately and secondly pooling together the two samplers, being the results very similar (same assemblages were obtained). Because of this, only pooled together results are explained in this paper. Pooling of beam and otter trawl was performed through a standardization to a common area $\left(\mathrm{kg} / \mathrm{km}^{2}\right)$, obtaining a unique data matrix.

Within the INDEMARES project $>800$ species have been recorded in the Galicia Bank. Nevertheless, for all multivariate analyses, epibenthic invertebrate species matrix was reduced, considering only those species with a biomass $>0.04 \%$ of the total biomass and a frequency of occurrence $>5 \%$, in order to reduce the variability in the matrix due to the high presence of zeros. The final set analysed consisted of 125 species (Annex 1).

This reduced matrix was log-transformed to minimize the effect of high values. To detect spatial patterns, a cluster analysis was applied using the Bray-Curtis similarity index. The distance matrix was processed with the UPGMA algorithm. Based on the groups obtained by cluster analysis, species responsible of intragroup similarity were identified using the SIMilarity PERcentage analysis (SIMPER). All these analyses were performed using PRIMER 6 package (Clarke and Warwick, 2001).

Differences between assemblages total biomass $\left(\mathrm{kg} / \mathrm{km}^{2}\right)$, species richness (number of species per sample) and Shannon diversity were determined using a Kruskal-Wallis one way ANOVA on ranks. When significant differences were detected, pairwise Dunn's tests were run to identify the assemblages responsible for such differences.

\subsection{Environmental characterization of assemblages}

Aiming to elucidate the effect of depth in the distribution of each species, the Center of Gravity (CoG: Stefanescu et al., 1992; Cartes et al., 2011) was estimated with the following equation:

$$
\operatorname{CoG}=\frac{\sum x_{i} * z_{i}}{\sum x_{i}}
$$

where $\mathrm{x}_{\mathrm{i}}$ is the biomass of the species in the sample $i$ and $\mathrm{z}_{\mathrm{i}}$ is the depth in this sample.

Effect of environmental variables in the spatial distribution of assemblages was determined using canonical analysis, available with the CANOCO 4.5 package (ter Braak and Smilauer, 2002) performed on the same biomass matrix used in cluster analysis. Before the application of direct gradient (canonical) analysis, the length of gradient of the logtransformed biomass per sample of invertebrate species, was assessed by means of Detrended Correspondence Analysis. The resulting gradients were short (below 2.5SD units), and consequently a linear ordination method was used by applying Redundancy Analysis (RDA). The explanatory variables considered were depth, near-bottom temperature, near-bottom salinity, and sediment characteristics, including mean particle diameter $\left(\mathrm{Q}_{50}\right)$, sorting coefficient $\left(\mathrm{S}_{0}\right)$, weight percentage of gravel and coarse sands $(>500 \mu \mathrm{m})$, of medium, fine and very fine sands $(63-500 \mu \mathrm{m})$, and mud $(<63 \mu \mathrm{m})$, and weight percentage of organic matter. The weight of coral framework (dead and alive aggregations and reefs of cold-water corals) has been included in the analysis since it was described as determinant to benthic diversity in previous studies (Cartes et al., 2014). Three nominal (categorical) variables have been also included: water mass affecting the sample (ENACW, MOW, LSW), year and sampling gear (beam trawl, otter trawl). Particle size analysis of sediments was performed by a combination of dry sieving and sedimentation techniques (Buchanan, 1984). Organic matter in the sediment was estimated as weight loss of dry $\left(100{ }^{\circ} \mathrm{C}, 24 \mathrm{~h}\right)$ weight after combustion $\left(500^{\circ} \mathrm{C}, 24 \mathrm{~h}\right)$.

The representativeness of the ordination analysis is given in terms of eigenvalues of the axes and variance explained by the biplots. The statistical significance was calculated with the Monte Carlo test (Verdonschot and Ter Braak, 1994) using 999 permutations under the reduced model. The significance of each environmental factor was tested by running the analysis with it as the variable and the other factors as covariables, and again calculated with the Monte Carlo test. Significance of groups obtained in the cluster analysis was also tested using the RDA model. Details of the model and procedure are described in Table 3. 
RDA results are presented graphically in a bi-dimensional ordination diagram generated by biplot scaling focused on inter-species distances, in which species are represented by points and environmental variables by vectors. The arrows of the explanatory variables indicate the direction of maximum change of these variables across the diagram. The projection of species categories onto an arrow gives an approximation of their weighted averages related to the variable.

\section{Results}

\subsection{Epibenthic assemblages}

Five main clusters were found, assuming an uneven level of similarity in assemblage determination for description purposes, as shown in Fig. 2. Boundaries between clusters were detected at depths 770, 800, 1000 and $1200 \mathrm{~m}$. First dichotomy splits the summit samples (737-1187 $\mathrm{m}$ ) and those obtained in the deeper bank flank (1460-1809 m) at a level of 92\% of dissimilarity. The first cluster groups samples of depths between 737 and $1187 \mathrm{~m}$ and the second, depths of 1460 to $1809 \mathrm{~m}$, with a sampling gap between both. Sediment type seem to have a role in the clustering, since the cluster comprising samples from the seamount summit is characterized by medium sands and that with samples of the bank flanks, by fine and very fine sands. Distribution of cluster groups along the GB topography is shown in Fig. 3.

The following dichotomy ( $80 \%$ dissimilarity), within the bank summit cluster, forms two groups, one clustering shallower sites in the range $730-1000 \mathrm{~m}$ and one comprising deeper samples from depths between 1000 and $1187 \mathrm{~m}$ located in the bank break (BB) · The group comprising shallower sites $(730-1000 \mathrm{~m})$ is further classified into three clusters after a first dichotomy (78\%) around $770 \mathrm{~m}$, and a second one (70\%) around $800 \mathrm{~m}$. This latter group can be easily identified with samples where cold-water coral reef was found. Gear used to obtain samples was not a decisive factor (except in cluster BB where otter and beam trawls are clustered separately).
SIMPER analysis (Table 1) highlights faunal differences between clusters and help to characterize the 5 assemblages identified:

i). Bank Summit $\left(\mathrm{BS}_{1}\right)$ ophiuroid assemblage: shallowest samples (730-770 m) dwelled by a large biomass $\left(1985 \mathrm{~kg} / \mathrm{km}^{2}\right.$ of ophiuroids of the family Ophiacanthidae (Ophiacantha densa, Ophiacanta sp. and Ophiomyces grandis) and Amphiuridae (Amphiura grandisquama), and by the solitary corals Deltocyathus moseleyi and Flabellum chunii, and the bivalve Limopsis minuta.

ii). Bank Summit $\left(\mathrm{BS}_{2}\right)$ Limopsis and Flabellum assemblage: samples in the range $770-800 \mathrm{~m}$, similar to the $\mathrm{BS}_{1}$, but without huge populations of ophiuroids. Typified by the small deep-sea bivalve Limopsis minuta, and the solitary coral Flabellum chunii, together with crawling crabs and shrimps.

iii). Bank Summit with $\mathrm{CW}$ coral reef ( $\mathrm{BS}_{\mathrm{rf}}$ ), at depths ranging from 800 to $1000 \mathrm{~m}$, covered by patches of cold-water coral colonies (Lophelia pertusa and Madrepora oculata, 315.5 and $306.0 \mathrm{~kg} / \mathrm{km}^{2}$ of live coral). Together with these two scleractinian species, typifying species are mostly sessile coral epibionts, such as the anthozoans Acanthogorgia armata, Desmophyllum dianthus, Parantipathes sp. and Swiftia rosea, the bivalves Lima marioni and Asperarca nodulosa, and crawling fauna such as different species of decapods crustaceans including Munidopsis spp. (most of which were M. serricornis), Munida tenuimana and Bathynectes maravigna.

iv). Bank Break (BB) Cidaris and Thenea assemblage: located in the range 1000-1200 $\mathrm{m}$ and dominated by the urchin Cidaris cidaris and the sponge Thenea muricata which explain together more than the $50 \%$ of the intragroup similarity. The seastar Plinthasther dentatus and the benthopelagic shrimps Aristaeopsis edwardsiana and Systellaspis debilis are secondary typifying species.

v). Bank Flanks (BF) Benthogone assemblage: Deepest assemblage (1400-1800 m) clearly dominated by the holothurian of the order Elasipodida Benthogone rosea $\left(628.2 \mathrm{~kg} / \mathrm{km}^{2}\right)$, accompanied by the leather urchin Araeosoma fenestratum, a very distinct arthropod fauna (the crab Neolithodes grimaldii,

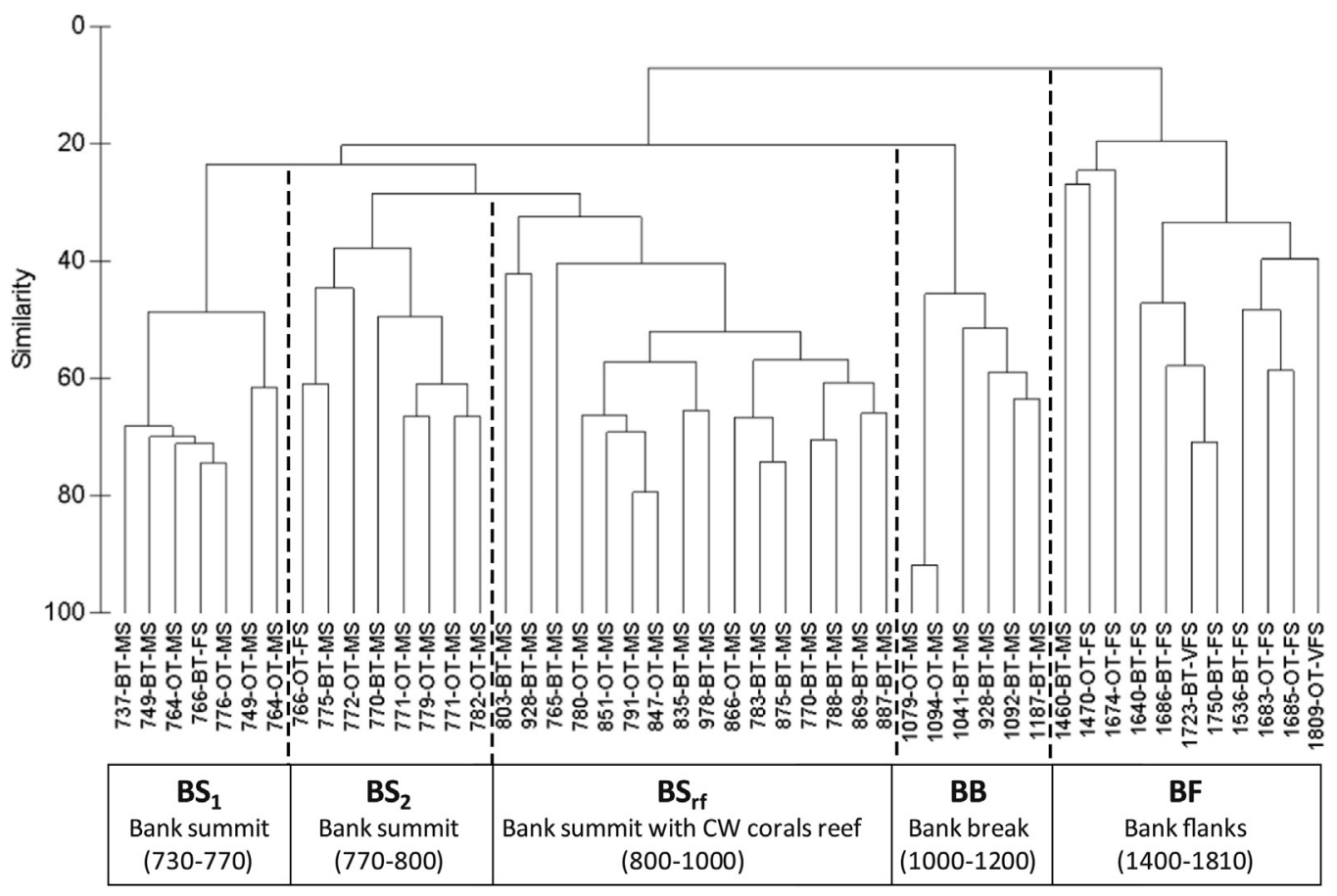

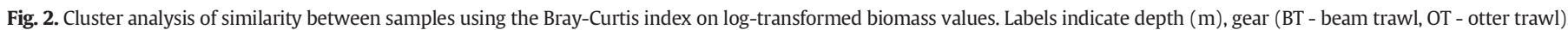
and sediment type (MS - medium sands, FS - fine sands, VFS: very fine sands). 


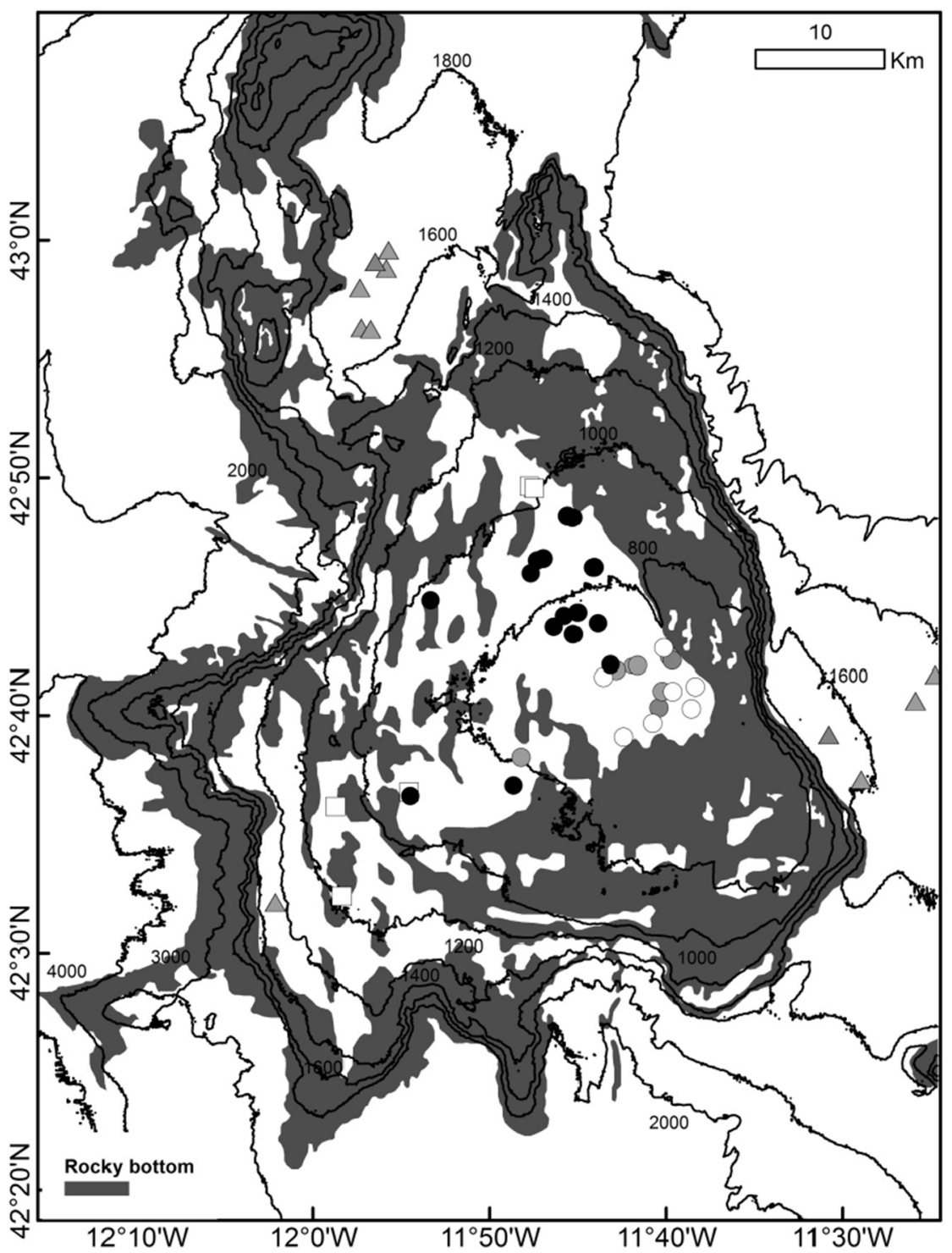

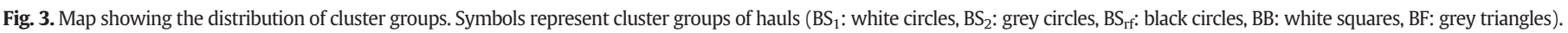

Glyphocrangon longirostris or the giant sea spider Colossendeis colossea), the scaphopod Fissidentalium capillosum, and several anthozoans including the solitary coral Stephanocyathus crassus, the seapen Umbellula sp., the bamboo coral Acanella arbuscula and the gorgonian Swiftia rosea.

\subsection{Patterns in bathymetric distribution of species}

A generalized species substitution with depth has been found. From the 125 species analysed, the higher proportion ( 71 species, $56 \%$ of the total set) appeared in a depth range narrower than $25 \%$ of the total depth range sampled. A second group of 36 species (29\% of total set) were distributed along $75 \%$ or more of the depth range explored.

Regarding frequency of occurrence (FO) from the total set only 7 species occurred in at least $50 \%$ of samples, whereas 53 species appeared in $<10 \%$ of the samples (Annex 1 ).

Clear depth boundaries characterized by high species renewal or substitution of species can be observed after plotting species first appearance/disappearance vs. depth (Fig. 4). There is a sharp appearance of species between 700 and $900-1000 \mathrm{~m}$, being the disappearance more progressive. Deeper than $1000 \mathrm{~m}$, few species appeared for the first time or disappeared. The range 1200-1485 m shows a gap corresponding with the slopes of the bank where no samples were obtained. In the 1485-1600 m stratum the number of species appearing and disappearing increases progressively, with a final plateau of appearance in the deepest samples, and the obvious sharp disappearance of remaining species.

These bathymetric boundaries are also evident in Fig. 5 where species CoG are plotted vs. depth. In this figure, a group of species is distributed with preference at depths shallower than $900 \mathrm{~m}$, and another group shows its preferences for the 1400-1800 m depth range. Two ways of utilization of GB depth strata are also evident, with species with wide distribution ranges and species with small distribution ranges. In the summit the number of species with wide depth range of distribution is lower than in the deeper bank flanks.

Some genera are represented in GB with two species that show different ecology (Fig. 5). For example in the pairs Polycheles typhlopsPolycheles laevis, Limopsis minuta-Limopsis cristata, Uropthychus rubrovittatus-Uropthychus concolor, Munida sarsi-Munida tenuimana, the former species prefer clearly shallower depths ( $<1000$ in P. typhlops, $<800$ in the rest), whereas the latter species of every pair have preference for deeper areas (>800 in M. tenuimana, and $>1400 \mathrm{~m}$ in the others) (Fig. 5, Annex 1).

Epibenthic biomass per haul as a function of depth is shown in Fig. 6 and in Table 2. Biomass followed a U-shaped profile with depth and 
Table 1

Cumulative contributions to the similarity (Cum. \%) of epibenthic megafauna species by depth range obtained by SIMPER analysis. Cut-off at cumulative contributions of $75 \%$

\begin{tabular}{|c|c|}
\hline & Cum \% \\
\hline \multicolumn{2}{|l|}{ Average similarity: 57.2} \\
\hline \multicolumn{2}{|c|}{$\mathrm{BS}_{1}$ - Bank Summit (730-770 m) } \\
\hline Ophiacantha densa & 12.5 \\
\hline Amphiura grandisquama & 24.6 \\
\hline Ophiomyces grandis & 36.1 \\
\hline Ophiacantha sp. & 46.7 \\
\hline Limopsis minuta & 66.4 \\
\hline Flabellum chunii & 74.5 \\
\hline Deltocyathus moseleyi & 78.6 \\
\hline \multicolumn{2}{|l|}{ Average similarity: 51.3} \\
\hline \multicolumn{2}{|c|}{$\mathrm{BS}_{\mathrm{rf}}$ - Bank Summit with coral reef $(780-1000 \mathrm{~m})$} \\
\hline Lophelia pertusa & 12.7 \\
\hline Madrepora oculata & 25.2 \\
\hline Munida tenuimana & 37.4 \\
\hline Acanthogorgia armata & 47.5 \\
\hline Desmophyllum dianthus & 54.8 \\
\hline Munidopsis spp. & 61.3 \\
\hline Parantipathes sp. & 66.1 \\
\hline Swiftia rosea & 69.6 \\
\hline Lima marioni & 72.5 \\
\hline Asperarca nodulosa & 74.8 \\
\hline Bathynectes maravigna & 77.2 \\
\hline \multicolumn{2}{|l|}{ Average similarity: 30.35} \\
\hline \multicolumn{2}{|l|}{ BB - Bank Break (1000-1200 m) } \\
\hline Cidaris cidaris & 36.1 \\
\hline Thenea muricata & 56.8 \\
\hline Plinthasther dentatus & 69.5 \\
\hline Aristaeopsis edwardsiana & 74.8 \\
\hline Systellaspis debilis & 75.2 \\
\hline \multicolumn{2}{|l|}{ Average similarity: 40.5} \\
\hline \multicolumn{2}{|l|}{$\mathrm{BS}_{2}$ - Bank Summit (780-800 m) } \\
\hline Limopsis minuta & 30.3 \\
\hline Flabellum chunii & 46.1 \\
\hline Cancer bellianus & 59.7 \\
\hline Chaceon affinis & 67.7 \\
\hline Plesionika martia & 72.9 \\
\hline Bathynectes maravigna & 75.1 \\
\hline \multicolumn{2}{|l|}{ Average similarity: 30.9} \\
\hline \multicolumn{2}{|c|}{ BF - Bank Flanks (1400-1800 m) } \\
\hline Benthogone rosea & 26.4 \\
\hline Neolithodes grimaldii & 36.8 \\
\hline Araeosoma spp. & 43.1 \\
\hline Stephanocyathus crassus & 49.0 \\
\hline Colossendeis colossea & 53.5 \\
\hline Glyphocrangon longirostris & 57.2 \\
\hline Fissidentalium capillosum & 60.1 \\
\hline Plinthasther dentatus & 62.7 \\
\hline Flabellum chunii & 65.3 \\
\hline Acanella arbuscula & 67.9 \\
\hline Parapagurus pilosimanus & 70.4 \\
\hline Umbellula sp. & 72.9 \\
\hline Limopsis cristata & 75.2 \\
\hline
\end{tabular}

highest biomass (Chi-sq. $=19.4, p=0.001$ ) was found at depths between 750 and $800 \mathrm{~m}$, in the $\mathrm{BS}_{1}$ ophiuroid assemblage, the second one in the range $1700-1800 \mathrm{~m}$, due to the holothurians of BF. Around $900 \mathrm{~m}$ biomass was also relatively high, attributable to cold-water corals of the $\mathrm{BS}_{\mathrm{rf}}$ assemblage.

Significant differences were also found in species richness (Chi-sq. $=$ 22.3; $p<0.001$ ) being $\mathrm{BS}_{\mathrm{rf}}$ the richest assemblage, followed by $\mathrm{BF}$ and $\mathrm{BS}_{1}$ (Table 2). $\mathrm{BS}_{1}$ and $\mathrm{BS}_{\mathrm{rf}}$ were the assemblages with a higher Shannon diversity (Chi-sq. $=22.3 ; p<0.001$, Table 2 ).

\subsection{Effects of environmental variables on species and assemblages} distribution

Environmental variables mean values between assemblages are summarized in Table 2. Greatest differences are in the substrate type

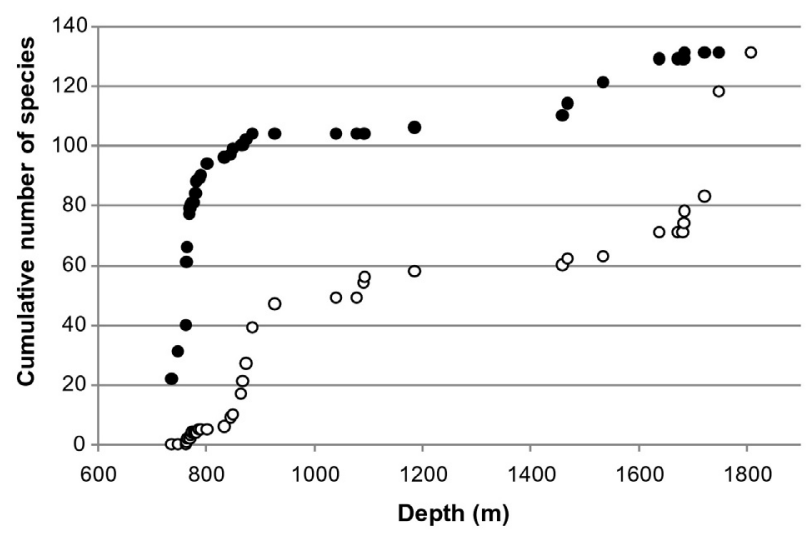

Fig. 4. Appearance $(\bullet)$ and disappearance $(O)$ of accumulative number of species as a function of depth on the Galicia Bank. Sampling gap between 1200 and 1400 m depth.

between summit (medium sands) and flanks (fine and very fine sands with higher organic content).

Assemblages obtained by means of cluster analysis are also consistent in RDA, where environmental variables are included in the analysis. RDA results are listed in Table 3. The full model, which included all the variables and the factor "year" and "sampler" as covariables, was highly significant ( $p=0.001$ ) and explained almost $50 \%$ of the total variance. The RDA applied separately for each environmental factor included as a variable and the others as covariables showed that all of them were significant except temperature and year. Depth was the main factor affecting the species composition, accounting for $13.1 \%$ of the explained variance (EV). After depth, the factor "Coral" is the second key variable (9.3\% EV) followed by sedimentary characteristics: the presence of coarse and medium sands (CS) and mud. These analyses did not detect significant variations in the species composition between the different surveys (years) and samplers. Using the RDA model on each cluster group as variable and all the environmental factors as covariables, all groups were significant (Table 3).

Fig. 7a shows the ordination of samples in relation to canonical axes (linear combination of environmental variables). Samples are distributed along two diagonal axes. The three summit assemblages are distributed along one of these axes (from the top left to the bottom right of the plot), with slight depth differences (730-800 m) and characterized all by medium sands with low organic content. $\mathrm{BS}_{1}$ is located in the deepest limit of influence of the ENACW, whereas $\mathrm{BS}_{2}$ and $\mathrm{BS}_{\mathrm{rf}}$ are influenced by the MOW. The key factor segregating these three groups along this axis is coral reef presence, splitting clearly those samples where habitat is defined by CW coral. The other diagonal axis, perpendicular to the summit one, is clearly a depth gradient from the summit group, to the deepest assemblage (BF), with the BB assemblage in the middle. The BB assemblage is located in the areas where slope increases, near the bank break, and is still characterized by medium sands. Finally, the BF assemblage, at depths between 1400 and $1800 \mathrm{~m}$, is typified by fine sands with a higher content of organic matter than the other assemblages. Distribution of cluster groups along canonical axis is in coherence with Fig. 2 and Fig. 3.

Fig. $7 \mathrm{~b}$ shows the faunal differences between assemblages and is in coherence with the SIMPER results (Table 1). Autoecological information of the species inhabiting the different environments can be obtained by combining RDA and SIMPER results, and also bearing in mind the results on faunal renewal described in Section 3.2.

\section{Discussion}

\subsection{Distribution of Galicia Bank epibenthic communities}

Galicia Bank harbors a singular and characteristic diversity of environments. The combined effects of depth, slope, substrate type and 


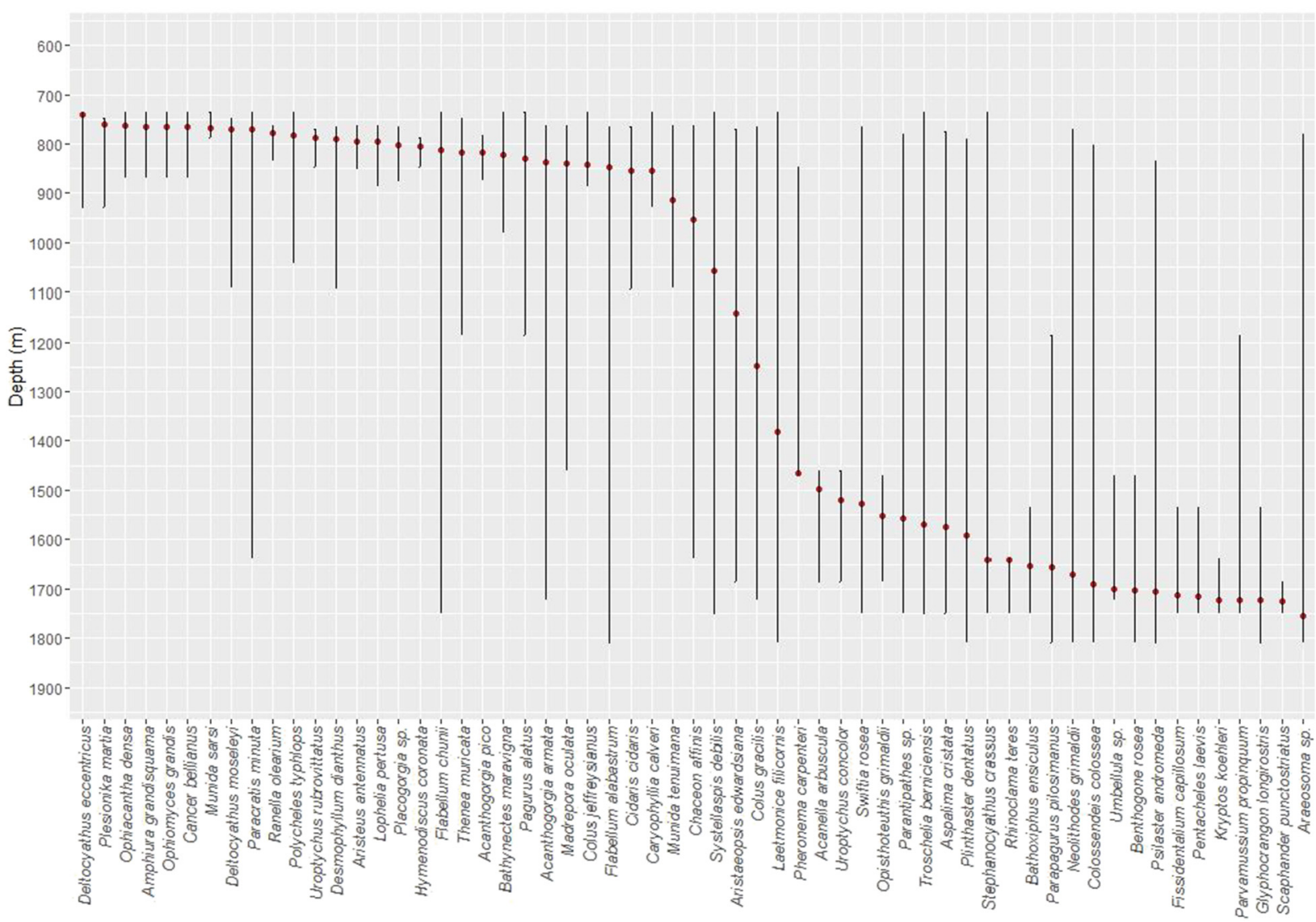

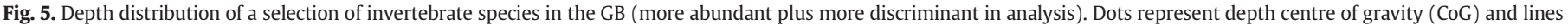
represent depth distribution range (maximum-minimum).

hydrographic gradients presumably shape habitats and communities distributions. Five epibenthic assemblages were identified in sedimentary habitats of the GB, typified by a fauna of deep sea invertebrates and characterized by different environmental conditions.

Boundaries between GB assemblages found in the present study are in coherence with the depth-related Atlantic NE zonation studies, but taking into account seamount topography, strong currents in the summit area and isolation from mainland as additional key factors. In most seamount studies, depth was the strongest environmental proxy for the community-structuring processes (McClain and Lundsten, 2014; Du Preez et al., 2016). Nevertheless, depth is a complex environmental factor which encompasses information of several variables such as near-bottom

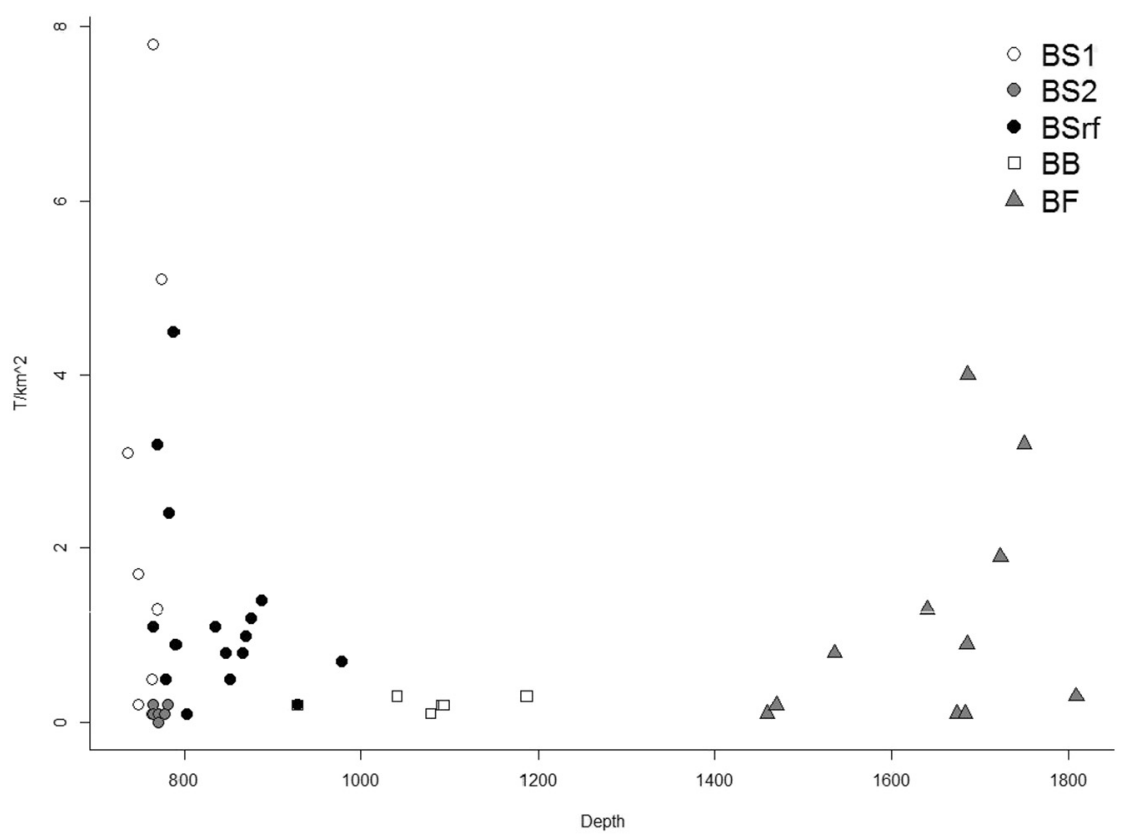

Fig. 6. Evolution of total biomass $\left(1000 \mathrm{~kg} / \mathrm{km}^{2}\right.$ ) versus depth of samples (symbols representing cluster groups). Sampling gap between 1200 and $1400 \mathrm{~m}$ depth. 
Table 2

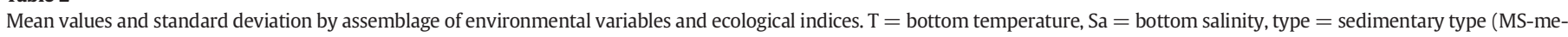

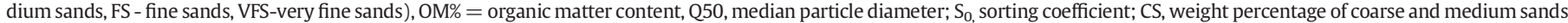

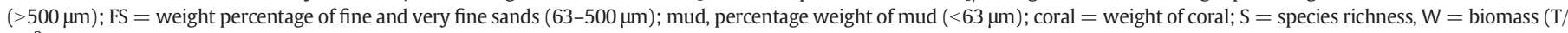
$\left.\mathrm{km}^{2}\right), \mathrm{H}^{\prime}=$ Shannon diversity.

\begin{tabular}{|c|c|c|c|c|c|c|c|c|c|c|c|c|c|c|c|}
\hline & & Depth & $\mathrm{T}$ & Sa & Type & OM\% & $\mathrm{Q}_{50}$ & $\mathrm{~S}_{\mathrm{o}}$ & CS & FS & Mud & Coral & $\mathrm{S}$ & W & $\mathrm{H}^{\prime}$ \\
\hline \multirow[t]{2}{*}{$\mathrm{BS}_{1}$} & Mean & 758.6 & 11.17 & 35.82 & MS & 1.85 & 295.5 & 1.45 & 17.03 & 82.07 & 0.91 & 0.0 & 20.86 & 2.81 & 1.92 \\
\hline & SD & 13.7 & 0.16 & 0.09 & & 0.22 & 30.9 & 0.06 & 4.24 & 4.21 & 0.50 & 0.0 & 3.58 & 2.75 & 0.45 \\
\hline \multirow[t]{2}{*}{$\mathrm{BS}_{2}$} & Mean & 771.4 & 11.16 & 35.83 & MS & 1.76 & 337.6 & 1.37 & 20.34 & 79.18 & 0.48 & 56.0 & 15.25 & 0.13 & 1.25 \\
\hline & SD & 6.4 & 0.21 & 0.13 & & 0.10 & 50.6 & 0.08 & 4.80 & 4.29 & 0.67 & 158.3 & 6.69 & 0.07 & 0.33 \\
\hline \multirow[t]{2}{*}{$\mathrm{BS}_{\mathrm{rf}}$} & Mean & 838.5 & 11.15 & 35.91 & MS & 1.56 & 308.5 & 1.36 & 15.05 & 84.37 & 0.57 & 574.2 & 28.63 & 1.29 & 1.85 \\
\hline & $\mathrm{SD}$ & 61.0 & 0.15 & 0.11 & & 0.19 & 34.36 & 0.05 & 5.19 & 5.18 & 0.67 & 605.3 & 7.86 & 1.16 & 0.30 \\
\hline \multirow[t]{2}{*}{ BB } & Mean & 1070.2 & 10.84 & 35.94 & MS & 1.52 & 352.02 & 1.37 & 22.21 & 76.82 & 0.96 & 49.3 & 9.67 & 0.22 & 1.29 \\
\hline & SD & 84.7 & 0.18 & 0.07 & & 0.21 & 37.67 & 0.03 & 6.39 & 6.13 & 1.01 & 120.7 & 3.67 & 0.08 & 0.39 \\
\hline \multirow[t]{2}{*}{$\mathrm{BF}$} & Mean & 1646.9 & 6.07 & 35.34 & FS/VFS & 2.72 & 179.15 & 1.99 & 5.68 & 81.96 & 12.36 & 0.0 & 22.64 & 1.17 & 1.26 \\
\hline & SD & 112.4 & 0.57 & 0.10 & & 0.87 & 65.01 & 0.85 & 3.81 & 15.46 & 17.19 & 0.0 & 9.76 & 1.34 & 0.70 \\
\hline
\end{tabular}

temperature, water masses, substrate type and slope, all of them suitable to be key factors controlling species distribution. This "depth" regulated environment generates communities which were generally distributed as bands encircling the seamount, either on the summit or on the flanks (Du Preez et al., 2016). In a wider context, depth is also considered the main factor in deep-sea ecosystems, with a consistent reporting of bands with faunal boundaries at 500-700, 1000-1400 m, 1600-2000 m and 2500-3000 m (Gage, 1986; Gage et al., 2000; Howell et al., 2002; Olabarria, 2005; Howell, 2010; Cartes et al., 2014), in part coincident with boundaries found at GB for epibenthos.

An outstanding result of the present study is the evidence of how epibenthic species have a differential use of these environmental bands offered by the GB. There are a higher amount of species showing an estenobathyal response (low depth range, low FO) versus a small number of eurybathyal ones (wide depth range, high FO). This fact is in coherence with the results of Cartes et al. (2014) on GB decapods crustaceans who found a low percentage of species appearing along $75 \%$ or more of the depth range explored or occurring in at least $50 \%$ of samples.

In consonance with this, renewal of some species related to habitat partitioning was especially clear in some congeneric pairs of species with non-overlapping distribution in the bank: Polycheles typhlops,

\section{Table 3}

Results of the redundancy analysis for the invertebrate species biomass matrix, showing the explained variance (EV) and the F-statistic for both the full model, which contains all the variables included in the model, and each individual variable after extracting the effect of the rest as covariables. Note that the sum of the EV for all variables is $>100 \%$ due to the shared variance. The levels of significance of each explanatory variable are also shown $\left({ }^{* *} p<0.01,{ }^{*} p<0.05\right.$ and $\left.-p>0.05\right)$.

\begin{tabular}{|c|c|c|c|c|}
\hline Effect & Covariable & EV & F-ratio & $p$-Value \\
\hline \multicolumn{5}{|c|}{ Variables included in the RDA } \\
\hline Full model & Sm, Y & $48.5 \%$ & 3.09 & $* *$ \\
\hline Depth (D) & $\mathrm{Sm}, \mathrm{Y}, \mathrm{T}, \mathrm{S}, \mathrm{Q}, \mathrm{G}_{1,2,3}, \mathrm{O}, \mathrm{S}_{0}, \mathrm{Co}_{0} \mathrm{~W}_{1,2,3}$ & $13.1 \%$ & 7.46 & $* *$ \\
\hline Temperature (T) & $\mathrm{Sm}, \mathrm{Y}, \mathrm{D}, \mathrm{S}, \mathrm{Q}, \mathrm{G}_{1,2,3}, \mathrm{O}, \mathrm{S}_{0}, \mathrm{Co}_{0} \mathrm{~W}_{1,2,3}$ & $0.7 \%$ & 0.89 & - \\
\hline Salinity $(S)$ & Sm,Y,D,T,Q, G $1,2,3, \mathrm{O}, \mathrm{S}_{0}, \mathrm{Co}_{\mathrm{W}} \mathrm{W}_{1,2,3}$ & $0.9 \%$ & 1.73 & $*$ \\
\hline $\mathrm{Q}_{50}(\mathrm{Q})$ & $\mathrm{Sm}, \mathrm{Y}, \mathrm{D}, \mathrm{T}, \mathrm{S}, \mathrm{G}_{1,2,3}, \mathrm{O}, \mathrm{S}_{0}, \mathrm{Co}_{0}, \mathrm{~W}_{1,2,3}$ & $2.0 \%$ & 1.43 & $*$ \\
\hline $\mathrm{CS}\left(\mathrm{G}_{1}\right)$ & $\mathrm{Sm}, \mathrm{Y}, \mathrm{D}, \mathrm{T}, \mathrm{S}, \mathrm{Q} \mathrm{G}_{2,3}, \mathrm{O}, \mathrm{S}_{0}, \mathrm{Co}_{\mathrm{W}} \mathrm{W}_{1,2,3}$ & $6.6 \%$ & 5.17 & $* *$ \\
\hline $\mathrm{FS}\left(\mathrm{G}_{2}\right)$ & Sm,Y,D,T,S,Q $G_{1,3}, O, S_{0}, C_{0}, W_{1,2,3}$ & $5.9 \%$ & 2.08 & $* *$ \\
\hline $\operatorname{Mud}\left(\mathrm{G}_{3}\right)$ & $\mathrm{Sm}, \mathrm{Y}, \mathrm{D}, \mathrm{T}, \mathrm{S}, \mathrm{Q}, \mathrm{G}_{1,2}, \mathrm{O}, \mathrm{S}_{0}, \mathrm{Co}_{0} \mathrm{~W}_{1,2,3}$ & $7.8 \%$ & 6.85 & $* *$ \\
\hline OM\% (O) & Sm,Y,D,T,S,Q $G_{1,2,3}, S_{0}, C_{0}, W_{1,2,3}$ & $1.9 \%$ & 7.61 & $* *$ \\
\hline Sorting coef. $\left(\mathrm{S}_{0}\right)$ & $\mathrm{Sm}, \mathrm{Y}, \mathrm{D}, \mathrm{T}, \mathrm{S}, \mathrm{Q}, \mathrm{G}_{1,2,3}, \mathrm{O}, \mathrm{Co}_{0}, \mathrm{~W}_{1,2,3}$ & $2.5 \%$ & 3.58 & $*$ \\
\hline Coral (Co) & $\mathrm{Sm}, \mathrm{Y}, \mathrm{D}, \mathrm{T}, \mathrm{S}, \mathrm{Q}, \mathrm{G}_{1,2,3}, \mathrm{O}, \mathrm{S}_{0}, \mathrm{~W}_{1,2,3}$ & $9.3 \%$ & 5.17 & $* *$ \\
\hline ENACW $\left(\mathrm{W}_{1}\right)$ & $\mathrm{Sm}, \mathrm{Y}, \mathrm{D}, \mathrm{T}, \mathrm{S}, \mathrm{Q}, \mathrm{G}_{1,2,3}, \mathrm{O}, \mathrm{S}_{0}, \mathrm{Co}_{2} \mathrm{~W}_{2,3}$ & $2.8 \%$ & 1.98 & $* *$ \\
\hline $\operatorname{MOW}\left(\mathrm{W}_{2}\right)$ & $\mathrm{Sm}, \mathrm{Y}, \mathrm{D}, \mathrm{T}, \mathrm{S}, \mathrm{Q}, \mathrm{G}_{1,2,3}, \mathrm{O}, \mathrm{S}_{0}, \mathrm{Co}_{\mathrm{W}} \mathrm{W}_{1,3}$ & $4.5 \%$ & 5.18 & $* *$ \\
\hline $\operatorname{LSW}\left(\mathrm{W}_{3}\right)$ & $\mathrm{Sm}, \mathrm{Y}, \mathrm{D}, \mathrm{T}, \mathrm{S}, \mathrm{Q}, \mathrm{G}_{1,2,3}, \mathrm{O}, \mathrm{S}_{0}, \mathrm{Co}_{\mathrm{W}} \mathrm{W}_{1,2}$ & $6.8 \%$ & 7.55 & $* *$ \\
\hline Year $(Y)$ & $\mathrm{Sm}, \mathrm{D}, \mathrm{T}, \mathrm{S}, \mathrm{Q}, \mathrm{G}_{1,2,3}, \mathrm{O}, \mathrm{S}_{0}, \mathrm{Co}_{0}, \mathrm{~W}_{1,2,3}$ & $0.7 \%$ & 0.98 & - \\
\hline Sampler (Sm) & $\mathrm{Y}, \mathrm{D}, \mathrm{T}, \mathrm{S}, \mathrm{Q}_{\mathrm{G}} \mathrm{G}_{1,2,3}, \mathrm{O}, \mathrm{S}_{0}, \mathrm{Co}_{\mathrm{N}} \mathrm{W}_{1,2,3}$ & $1.5 \%$ & 2.61 & $*$ \\
\hline \multicolumn{5}{|c|}{ Variables not included in the RDA } \\
\hline Cluster $\mathrm{BS}_{1}$ & $\mathrm{Sm}, \mathrm{Y}, \mathrm{D}, \mathrm{T}, \mathrm{S}, \mathrm{Q}, \mathrm{G}_{1,2,3}, \mathrm{O}, \mathrm{S}_{0}, \mathrm{C}_{0}, \mathrm{~W}_{1,2,3}$ & $6.1 \%$ & 4.63 & $* *$ \\
\hline Cluster $\mathrm{BS}_{2}$ & Sm,Y,D,T,S,Q, G ${ }_{1,2,3}, \mathrm{O}_{1} \mathrm{~S}_{0}, \mathrm{Co}_{0}, \mathrm{~W}_{1,2,3}$ & $2.5 \%$ & 2.69 & $* *$ \\
\hline Cluster $\mathrm{BS}_{\mathrm{rf}}$ & Sm,Y,D,T,S,Q $G_{1,2,3}, \mathrm{O}_{1} \mathrm{~S}_{0}, \mathrm{Co}_{0}, \mathrm{~W}_{1,2,3}$ & $7.3 \%$ & 6.99 & $* *$ \\
\hline Cluster BB & $\mathrm{Sm}, \mathrm{Y}, \mathrm{D}, \mathrm{T}, \mathrm{S}, \mathrm{Q}_{\mathrm{G}} \mathrm{H}_{1,2,3}, \mathrm{O}, \mathrm{S}_{0}, \mathrm{Co}_{0} \mathrm{~W}_{1,2,3}$ & $3.7 \%$ & 3.42 & $* *$ \\
\hline Cluster BF & Sm,Y,D,T,S,Q $G_{1,2,3}, \mathrm{O}, \mathrm{S}_{0}, \mathrm{Co}_{0}, \mathrm{~W}_{1,2,3}$ & $7.5 \%$ & 7.89 & $* *$ \\
\hline
\end{tabular}

Limopsis minuta, Uropthychus rubrovittatus and Munida sarsi prefer the shallower areas of the bank whereas Polycheles laevis, Limopsis cristata, Uropthychus concolor, and Munida tenuimana presented distributions on deeper bottoms (Fig. 7, Annex 1). Substitution of species that occupy a similar trophic niche, typically close species from a phylogenetic point of view, is a mechanism to avoid competence, and has been documented in oligotrophic areas, such as the deep Mediterranean (Cartes and Abelló, 1992; Cartes, 1993, 1998). GB has also some oligotrophic characteristics since epibenthic and endobenthic environments are impoverished (low mainland advection, strong summit currents, Duineveld et al., 2004; Surugiu et al., 2008) and near-bottom zooplankton is abundant (Papiol et al., 2014). In this sense, deposit feeders are less abundant that filter feeders in the GB summit and when occurring, in the depositionary areas of the flanks, they are represented by rather K-strategists like the holothuroid Benthosema rosea (see below).

\subsection{Variables typifying communities and species distribution}

The shallowest assemblage, with sediment mainly composed by medium sands and typified by ophiuroids $\left(\mathrm{BS}_{1}, 730-770 \mathrm{~m}\right.$ ) corresponds with the upper slope zone in the continental shelf, which ranges from the shelf slope break (depth of the seasonal thermocline) in the continent to the first faunal discontinuity, which in this region lies at approximately $750 \mathrm{~m}$. The $750 \mathrm{~m}$ boundary is associated with the top of the permanent thermocline, the $10{ }^{\circ} \mathrm{C}$ isotherm, and the boundary between ENACW and MOW. Several assemblages similar to the $\mathrm{BS}_{1}$ habitat have been described in the literature at similar depths. Moreover, besides coral and sponges, echinoderms were revealed as one of the key taxa typifying deep sea assemblages (Howell et al., 2002; Metaxas and Giffin, 2004). Metaxas and Giffin (2004) described dense beds of Ophiacantidae (Ophiacantha abyssicola), in sedimentary areas of Nova Scotia, in depths similar to BS 1 on GB. Cherbonnier and Sibuet (1972) and Gage et al. (1983) described the bathymetrical preference of the species Ophiomyces grandis for the 200-700 m range. The spatial distribution of GB ophiuroids in an area of strong currents (presence of megaripples) could be a consequence of trophic-hydrographic drivers. Dense populations of Ophiocten gracilis able to intercept particles from near-bed flow (Gage, 1983), coincided with the slope current and largely disappeared at $1000 \mathrm{~m}$ at the Hebridan slope (Lamont and Gage, 1998; Gage et al., 2000). However, at those mainland continental slopes, macrobenthos at $700 \mathrm{~m}$ were represented not only by dense Ophiocten gracilis, but also by deposit feeder spatangoids urchins (Gage et al., 2000). The low contribution of deposit feeders at GB summit must be due to the low OM\% (around 1.7\%, Table 2) in this area compared with continental sedimentary slopes (e.g. in the Balearic Basin, muddy sediments has 4-8 OM\%; Cartes et al., 2008, 2009). We argued above about the possible causes of this benthic organic impoverishment: strong currents winnowing organic material (Duineveld et al., 2004), together with an absence of advective inputs from mainland (Surugiu et al., 2008). 

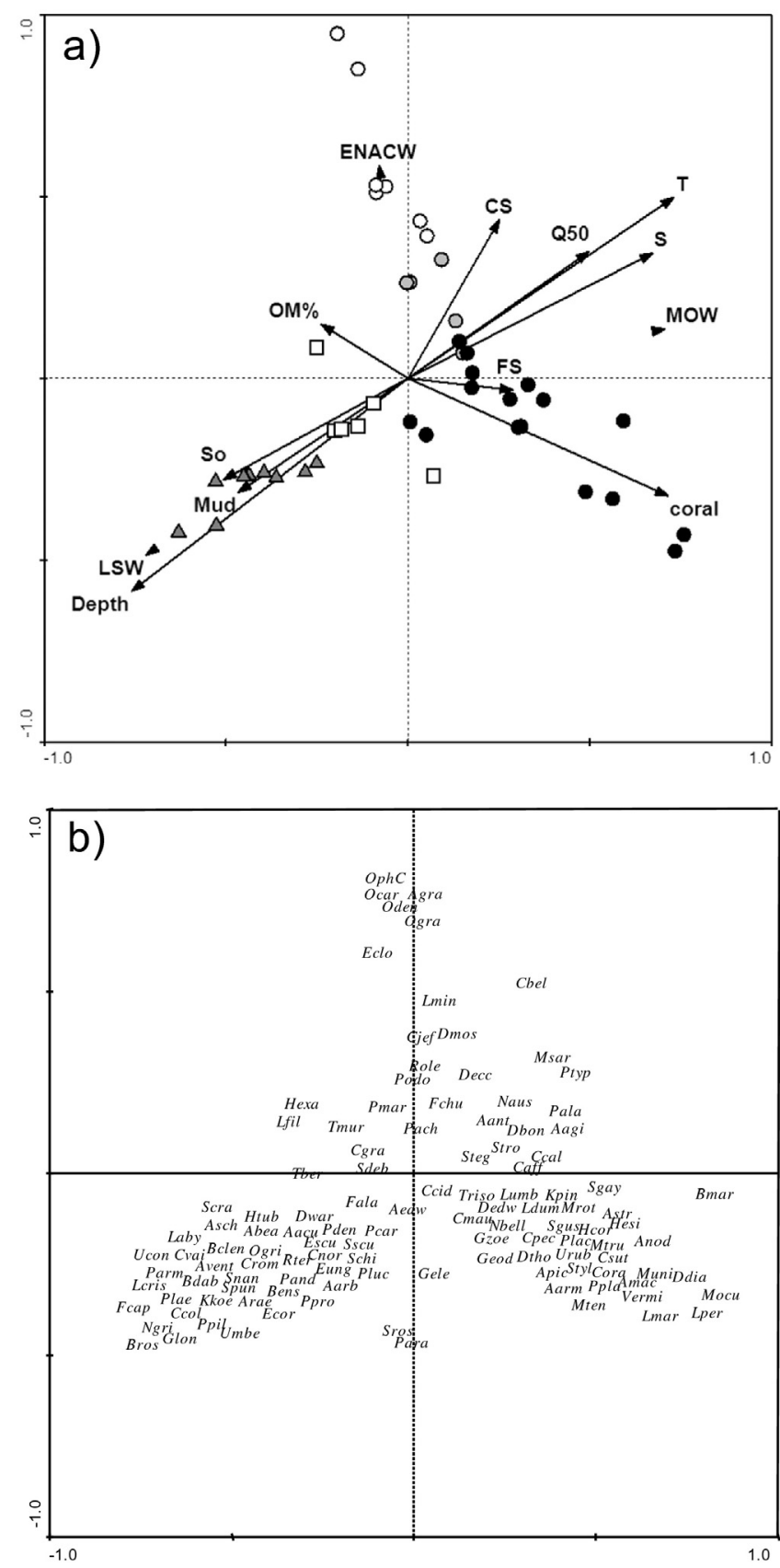

Fig. 7. RDA biplots. a) Environmental variables versus hauls. Symbols represent cluster groups of hauls $\left(\mathrm{BS}_{1}\right.$ : white circles, $\mathrm{BS}_{2}$ : grey circles, BSrf: black circles, $\mathrm{BB}$ : white squares, $\mathrm{BF}$ : grey triangles). $\mathrm{Q}_{50}$, median particle diameter; $\mathrm{S}_{0}$, sorting coefficient; $\mathrm{CS}$, weight percentage of coarse and medium sands $(>500 \mu \mathrm{m}) ; \mathrm{FS}=$ weight percentage of fine and very fine sands $(63-500 \mu \mathrm{m})$; mud, percentage weight of mud $(<63 \mu \mathrm{m}) ; 0$ OM\%, weight percentage of organic matter. b) Species. Areas represent groups of hauls. Species codes are in Annex 1.

Some Ophiacantha species can act as deposit feeder or suspension feeder depending of resource availability (Gallagher et al., 1998), while Amphiura are suspension feeders (Loo et al., 1996) recycling sinking particulate material (marine snow). The depleted $\delta^{13} \mathrm{C}$ signal found for $\mathrm{GB}$ ophiuroids at $\mathrm{BS}_{1}(-22.7 \%$, authors unp. data), more depleted than the lowest values found in other areas for deep mesopelagic zooplankton ( $-21.76 \%$, Fanelli et al., 2011), suggest they are suspension feeders (e.g. Amphipholis squamata) which main food source must be marine snow generated by zooplankton over GB summit. Over GB summit near-bottom zooplankton reached relatively high biomass (5.2 gWW/1000 $\mathrm{m}^{3}$, Papiol et al., 2014), being the only food source for epibenthos and fish (Preciado et al., 2016).
$\mathrm{BS}_{2}$ is an assemblage located in medium sands, deeper than the area of distribution of dense populations of ophiuroids and shallower than coldwater coral reef, and characterized for the small bivalve Limopsis minuta and the solitary coral Flabellum chunii. The $\mathrm{OM}$ in $\mathrm{BS}_{2}$ decreased probably due to higher hydrodynamism associated with steeper slope at $\mathrm{BS}_{2}$ stations. The fall of ophiuroids could be also due to such presumable higher disturbance, more than to the decrease of OM. A regime of strong bottom currents favors coarser sediments and low benthos biomass, as happens at the shelf break over Hebridan slope (Gage et al., 2000) or in the Balearic Islands for hyperbenthic peracarids (Cartes et al., 2008). At these more disturbed levels ophiuroids are practically absent.

On the GB at $800 \mathrm{~m}$ the $\mathrm{BS}_{\mathrm{rf}}$ assemblage appears (Lophelia and Madrepora reef on medium sands, $800-1000 \mathrm{~m}$ ). This zone, defined in the continent as the upper bathyal zone, ranges from the first faunal discontinuity to the second, which in this region is broadly defined as 750$1100 \mathrm{~m}$ (Howell et al., 2010). The $1100 \mathrm{~m}$ boundary is associated with changes in slope gradient, current speed, and food supply, which on the GB corresponds to the beginning of the summit break. Sánchez et al. (2014) described that the presence of living cold-water reefs is directly related to a high-energy environment at depths between 700 and $1200 \mathrm{~m}$, between the lower boundary of ENACW and the core of MOW, in a depth range that matches the water density range $\sigma_{\theta}=27.35-$ $27.65 \mathrm{~kg} \mathrm{~m}^{-3}$ that has been identified as the limit range for cold-water coral distribution in the North Atlantic. $\mathrm{BS}_{\text {rf }}$ presented significantly highest values of species richness and diversity. Cold-water corals form complex three-dimensional structures that support a diverse macroand mega-faunal community, by enhancing habitat complexity and heterogeneity, and providing attachment substrate, shelter, feeding, spawning and nursery areas for fish and invertebrate species (Henry and Roberts, 2007; Buhl-Mortensen et al., 2010).

Seamount conditions favor the presence of sessile-vulnerable filterfeeder species such as corals and sponges (Auster et al., 2005; Samadi et al., 2007; Rowden et al., 2010). Sessile filter feeders rely on currents to provide nutrition as well as to remove sediments that may smother them. Consequently, they are usually associated with strong current velocities or unique current patterns such as recirculation gyres, which in turn are indicative of increased concentrations of particles (Moore and Bullis, 1960, Tendal, 1992). GB cold-water coral reefs are located in areas of stronger hydrodinamism such as megaripple sandy areas of the summit and southern slope facing northward currents (Prieto et al., 2013).

In the outer part of the summit, the bank break (BB) assemblage was found. This area corresponds with the limit between the upper and the mid bathyal zone, and is typified by the urchin Cidaris cidaris and the sponge Thenea muricata. This assemblage is characterized by a different relief and a higher slope, with patches of medium sands surrounded of rocky outcrops. Flow acceleration on upper flanks of seamounts may lead to low sedimentation, hence a higher presence of rock (Boehlert and Genin, 1987) and low OM (1.66\%) in the sediments. This habitat is located in the area of influence of the core of MOW (Iorga and Lozier, 1999; Cartes et al., 2014). MOW influence, characterized by higher S and T (Iorga and Lozier, 1999; Fig. 7) of the water mass, coincided in its core distribution with a general impoverishment of fauna (emptiness of species observed in RDA plot with MOW) and of biomass (Fig. 6). This faunistic belt had the lowest diversity in GB and it is, in this sense, similar to the shelf slope break of continent areas (Gage et al., 2000; Cartes et al., 2008), located at shallower depths (150-300 m).

The deepest assemblage, $\mathrm{BF}$, located on the bank flanks beside GB covered by sediments with a high content of mud, and typified by the holothurians Benthogone rosea, correspond with the mid bathyal zone, which in this region lies between 1100 and $1800 \mathrm{~m}$. In the BF there was a significant increase in OM\% (mean $=1.80 \%$ ), especially in the deepest areas (reaching 3.2-3.5\% in the deepest samples). The $1800 \mathrm{~m}$ boundary is associated with the bottom of the permanent thermocline, the $4{ }^{\circ} \mathrm{C}$ isotherm and the boundary between MOW and LSW, which could cause changes in food supply and the increase in OM\% (Howell 
et al., 2010). Higher OM\% likely favored the dominance of $B$. rosea, which is a deposit feeder that seems to couple its biological cycle to spring phytodetritus inputs in the Atlantic. Still, OM\% values in the sediments were below those found on mainland slopes. Benthogone rosea have large eggs that develop into a juvenile without a larval stage (Hudson et al., 2004), so it is a K-strategist species probably adapted to depths with low trophic resources. At 1500-1800 m, coinciding with the depth occupied by BF assemblage, slow-growing lithodids were the dominant decapods among epibenthic invertebrates (Cartes et al., 2014). Lithodids also have life history adaptations (prolonged brooding of embryos, delayed age at maturity (Thatje, 2004) of a K-strategist.

As conclusion, results in the present study show that epibenthic species in this deep seamount are in general controlled by the same factors than other deep sea ecosystems, mainly depth and substrate type, but also by other seamount-related environmental characteristics such as the influence of different water masses, the low OM\% in sediments, attributable to strong currents and mainland isolation, and sea floor inclination. All this factors explain changes in epibenthic biomass.

\section{Acknowledgments}

This study was financed by the EC contract INDEMARES-LIFE (07/ NAT/E/000732). We thank all the participants and crews of the cruises Ecomarg0709, BanGal0810 and BanGal0811 performed, respectively, on board R/Vs Cornide de Saavedra, Thalassa and Miguel Oliver, and all the members of the Indemares-Bangal project team.

Annex 1. List of species analysed. Code $=$ abbreviature used in the RDA biplots, Min $\mathrm{Z}$ and Max $\mathrm{Z}=$ minimum and maximum depth ( $\mathrm{m}$ ), $\operatorname{cog} Z=$ centre of gravity for depth, $\%$ range $Z=$ percentage of total depth where this species appear, FO $\%=$ frequency of occurrence

\begin{tabular}{|c|c|c|c|c|c|c|c|}
\hline Code & Species & Taxon & $\operatorname{Min} Z$ & Max Z & $\operatorname{cog} Z$ & $\%$ range $\mathrm{Z}$ & FO\% \\
\hline Aarb & Acanella arbuscula & Cnidaria Anthozoa & 1460 & 1685 & 1498.2 & 21.0 & 8.3 \\
\hline Aarm & Acanthogorgia armata & Cnidaria Anthozoa & 764 & 1723 & 837.7 & 89.5 & 25.0 \\
\hline Apic & Acanthogorgia pico & Cnidaria Anthozoa & 783 & 875 & 818.7 & 8.6 & 6.3 \\
\hline Avent & Aegiochus ventrosa & Crustacea Isopoda & 1536 & 1750 & 1669.7 & 20.0 & 6.3 \\
\hline Amac & Alpheus macrocheles & Crustacea Decapoda & 765 & 928 & 792.5 & 15.2 & 22.9 \\
\hline Aacu & Amphissa acutecostata & Mollusca Gastropoda & 749 & 1723 & 1713.6 & 90.9 & 6.3 \\
\hline Agra & Amphiura grandisquama & Echinodermata Ophiuroidea & 737 & 869 & 764.8 & 12.3 & 18.8 \\
\hline Asch & Anatoma schioettei & Mollusca Gastropoda & 803 & 1750 & 1564.0 & 88.3 & 6.3 \\
\hline Aagi & Antalis agilis & Mollusca Scaphopoda & 737 & 1640 & 867.1 & 84.2 & 29.2 \\
\hline Abea & Aphrocallistes beatrix & Porifera Hexactinellida & 803 & 1750 & 1258.9 & 88.3 & 6.3 \\
\hline Arae & Araeosoma sp. & Echinodermata Echinoidea & 780 & 1809 & 1755.8 & 96.0 & 8.3 \\
\hline Aedw & Aristaeopsis edwardsiana & Crustacea Decapoda & 771 & 1685 & 1141.0 & 85.3 & 22.9 \\
\hline Aant & Aristeus antennatus & Crustacea Decapoda & 764 & 851 & 794.0 & 8.1 & 12.5 \\
\hline Anod & Asperarca nodulosa & Mollusca Bivalvia & 765 & 1460 & 862.2 & 64.8 & 31.3 \\
\hline Astr & Astrophorina undet. & Porifera Demospongia & 764 & 1470 & 825.2 & 65.9 & 22.9 \\
\hline Bens & Bathoxiphus ensiculus & Mollusca Scaphopoda & 1536 & 1750 & 1654.0 & 20.0 & 10.4 \\
\hline Bmar & Bathynectes maravigna & Crustacea Decapoda & 737 & 978 & 821.4 & 22.5 & 52.1 \\
\hline Bros & Benthogone rosea & Echinodermata Holothuroidea & 1470 & 1809 & 1704.3 & 31.6 & 20.8 \\
\hline Bdab & Boreotrophon dabneyi & Mollusca Gastropoda & 1640 & 1750 & 1731.0 & 10.3 & 6.3 \\
\hline Bclen & Brocchinia cf. clenchi & Mollusca Gastropoda & 1686 & 1809 & 1739.0 & 11.5 & 6.3 \\
\hline Cmau & Calliostoma maurolici & Mollusca Gastropoda & 770 & 772 & 771.2 & 0.2 & 6.3 \\
\hline Cvai & Calliotropis vaillanti & Mollusca Gastropoda & 1640 & 1750 & 1727.2 & 10.3 & 6.3 \\
\hline Csut & Callumbonella suturalis & Mollusca Gastropoda & 765 & 928 & 807.3 & 15.2 & 14.6 \\
\hline Cbel & Cancer bellianus & Crustacea Decapoda & 737 & 866 & 766.3 & 12.0 & 45.8 \\
\hline Ccal & Caryophyllia calveri & Cnidaria Anthozoa & 737 & 928 & 855.8 & 17.8 & 14.6 \\
\hline Caff & Chaceon affinis & Crustacea Decapoda & 764 & 1640 & 954.5 & 81.7 & 37.5 \\
\hline Ccid & Cidaris cidaris & Echinodermata Echinoidea & 766 & 1094 & 855.7 & 30.6 & 33.3 \\
\hline Cirr & Cirripedia undet & Crustacea Cirripeda & 772 & 1640 & 1339.6 & 81.0 & 14.6 \\
\hline Crom & Cirsonella romettensis & Mollusca Gastropoda & 1640 & 1750 & 1747.0 & 10.3 & 6.3 \\
\hline Ccol & Colossendeis colossea & Pycnogonida & 803 & 1809 & 1691.2 & 93.8 & 16.7 \\
\hline Cgra & Colus gracilis & Mollusca Gastropoda & 765 & 1723 & 1248.4 & 89.4 & 25.0 \\
\hline Cjef & Colus jeffreysianus & Mollusca Gastropoda & 737 & 887 & 841.4 & 14.0 & 6.3 \\
\hline Cora & Coralliophila sp. & Mollusca Gastropoda & 765 & 875 & 786.5 & 10.3 & 10.4 \\
\hline Crin & Crinoidea undet. & Echinodermata Crinoidea & 887 & 1750 & 1512.6 & 80.5 & 8.3 \\
\hline Cpec & Cryptolaria pectinata & Cnidaria Hydrozoa & 766 & 866 & 822.6 & 9.3 & 10.4 \\
\hline Cnor & Cymonomus normani & Crustacea Decapoda & 1460 & 1640 & 1545.3 & 16.8 & 6.3 \\
\hline Dwar & Dacrydium wareni & Mollusca Bivalvia & 851 & 1750 & 1601.4 & 83.9 & 6.3 \\
\hline Decc & Deltocyathus eccentricus & Cnidaria Anthozoa & 737 & 928 & 741.0 & 17.8 & 18.8 \\
\hline Dmos & Deltocyathus moseleyi & Cnidaria Anthozoa & 749 & 1092 & 769.6 & 32.0 & 25.0 \\
\hline Ddia & Desmophyllum dianthus & Cnidaria Anthozoa & 765 & 1094 & 790.4 & 30.7 & 29.2 \\
\hline Dbon & Dichelopandalus bonnieri & Crustacea Decapoda & 771 & 847 & 781.6 & 7.1 & 14.6 \\
\hline Dedw & Diodora edwardsi & Mollusca Gastropoda & 780 & 887 & 869.1 & 10.0 & 6.3 \\
\hline Dtho & Dorhynchus thomsoni & Crustacea Decapoda & 743 & 1640 & 1008.4 & 83.7 & 27.1 \\
\hline Ecor & Ennucula corbuloides & Mollusca Bivalvia & 1640 & 1750 & 1726.2 & 10.3 & 6.3 \\
\hline Epiz & Epizoanthus sp. & Cnidaria Anthozoa & 765 & 1723 & 828.7 & 89.4 & 37.5 \\
\hline Eclo & Ergasticus clouei & Crustacea Decapoda & 737 & 766 & 768.3 & 2.7 & 8.3 \\
\hline Ehan & Eucopia unguiculata & Crustacea Lophogastrida & 803 & 1750 & 1279.4 & 88.3 & 27.1 \\
\hline Escu & Eucopia sculpticauda & Crustacea Lophogastrida & 1460 & 1536 & 1492.3 & 7.1 & 8.3 \\
\hline Enor & Eunice norvegica & Annelida Polychaeta & 765 & 887 & 825.9 & 11.4 & 29.2 \\
\hline Fcap & Fissidentalium capillosum & Mollusca Scaphopoda & 1536 & 1750 & 1713.3 & 20.0 & 12.5 \\
\hline Fala & Flabellum alabastrum & Cnidaria Anthozoa & 766 & 1809 & 846.2 & 97.3 & 14.6 \\
\hline Fchu & Flabellum chunii & Cnidaria Anthozoa & 737 & 1750 & 813.5 & 94.5 & 64.6 \\
\hline Gele & Gennadas elegans & Crustacea Decapoda & 770 & 1750 & 1132.2 & 91.4 & 37.5 \\
\hline Geod & Geodia sp. & Porifera Demospongia & 770 & 869 & 787.2 & 9.2 & 14.6 \\
\hline Glon & Glyphocrangon longirostris & Crustacea Decapoda & 1536 & 1809 & 1723.9 & 25.5 & 16.7 \\
\hline
\end{tabular}


Annex 1 (continued)

\begin{tabular}{|c|c|c|c|c|c|c|c|}
\hline Code & Species & Taxon & $\operatorname{Min} \mathrm{Z}$ & $\operatorname{Max} Z$ & $\operatorname{cog} Z$ & $\%$ range $Z$ & FO $\%$ \\
\hline Gzoe & Gnathophausia zoea & Crustacea Lophogastrida & 749 & 1809 & 996.8 & 98.9 & 75.0 \\
\hline Hesi & Hesionidae undet. & Annelida Polychaeta & 765 & 887 & 827.8 & 11.4 & 18.8 \\
\hline Hexa & Hexactinellida undet. & Porifera Hexactinellida & 749 & 1674 & 1499.0 & 86.3 & 29.2 \\
\hline Htub & Hyalinoecia tubicola & Annelida Polychaeta & 1470 & 1809 & 1716.8 & 31.6 & 8.3 \\
\hline Hcor & Hymenodiscus coronata & Echinodermata Asteroidea & 788 & 847 & 805.9 & 5.5 & 8.3 \\
\hline Kpin & Kirchenpaueria pinnata & Cnidaria Hydrozoa & 765 & 866 & 788.2 & 9.4 & 8.3 \\
\hline Kkoe & Kryptos koehleri & Mollusca Gastropoda & 1640 & 1750 & 1723.1 & 10.3 & 8.3 \\
\hline Lfil & Laetmonice filicornis & Annelida Polychaeta & 737 & 1809 & 1382.1 & 100.0 & 16.7 \\
\hline Ldum & Lafoea dumosa & Cnidaria Hydrozoa & 765 & 866 & 789.1 & 9.4 & 10.4 \\
\hline Lmar & Lima marioni & Mollusca Bivalvia & 765 & 1640 & 845.8 & 81.6 & 39.6 \\
\hline Lcris & Limopsis cristata & Mollusca Bivalvia & 775 & 1750 & 1574.6 & 91.0 & 12.5 \\
\hline Lmin & Limopsis minuta & Mollusca Bivalvia & 737 & 1640 & 770.4 & 84.2 & 31.3 \\
\hline Lper & Lophelia pertusa & Cnidaria Anthozoa & 764 & 887 & 794.7 & 11.5 & 31.3 \\
\hline Lumb & Lumbrineris sp. & Annelida Polychaeta & 765 & 887 & 883.2 & 11.4 & 8.3 \\
\hline Laby & Lyonsiella abyssicola & Mollusca Bivalvia & 1640 & 1750 & 1703.0 & 10.3 & 6.3 \\
\hline Mocu & Madrepora oculata & Cnidaria Anthozoa & 764 & 1460 & 840.8 & 64.9 & 37.5 \\
\hline Mtru & Megerlia truncata & Brachiopoda & 765 & 875 & 828.8 & 10.3 & 12.5 \\
\hline Mrot & Modeeria rotunda & Cnidaria Hydrozoa & 765 & 866 & 789.1 & 9.4 & 10.4 \\
\hline Msar & Munida sarsi & Crustacea Decapoda & 737 & 788 & 769.0 & 4.8 & 29.2 \\
\hline Mten & Munida tenuimana & Crustacea Decapoda & 764 & 1092 & 915.0 & 30.6 & 33.3 \\
\hline Muni & Munidopsis serricornis \& spp. & Crustacea Decapoda & 770 & 887 & 840.4 & 10.9 & 29.2 \\
\hline Nbell & Narella bellissima & Cnidaria Anthozoa & 866 & 1092 & 948.3 & 21.1 & 6.3 \\
\hline Naus & Nausithoe sp. & Cnidaria Scyphozoa & 737 & 875 & 775.6 & 12.9 & 12.5 \\
\hline Ngri & Neolithodes grimaldii & Crustacea Decapoda & 770 & 1809 & 1670.9 & 96.9 & 16.7 \\
\hline Oden & Ophiacantha densa & Echiodermata Ophiuroidea & 737 & 869 & 764.0 & 12.3 & 18.8 \\
\hline OphC & Ophiacantha sp. & Echiodermata Ophiuroidea & 737 & 775 & 763.8 & 3.5 & 16.7 \\
\hline Ogra & Ophiomyces grandis & Echiodermata Ophiuroidea & 737 & 869 & 765.2 & 12.3 & 18.8 \\
\hline Ocar & Ophiura carnea & Echiodermata Ophiuroidea & 737 & 865 & 763.8 & 11.9 & 16.7 \\
\hline Ogri & Opisthoteuthis grimaldii & Mollusca Cephalopoda & 1470 & 1685 & 1551.6 & 20.1 & 6.3 \\
\hline Pach & Pachastrellidae undet. & Porifera Demospongia & 764 & 978 & 880.1 & 20.0 & 6.3 \\
\hline Pala & Pagurus alatus & Crustacea Decapoda & 737 & 1187 & 829.1 & 42.0 & 52.1 \\
\hline Para & Parantipathes sp. & Cnidaria Anthozoa & 780 & 1750 & 1557.8 & 90.5 & 37.5 \\
\hline Ppil & Parapagurus pilosimanus & Crustacea Decapoda & 1187 & 1809 & 1655.1 & 58.0 & 16.7 \\
\hline Ppro & Parvamussium propinquum & Mollusca Bivalvia & 1187 & 1750 & 1723.5 & 52.5 & 6.3 \\
\hline Ppla & Peltaster placenta & Echinodermata Asteroidea & 783 & 1041 & 842.6 & 24.1 & 12.5 \\
\hline Parm & Petalophthalmus papilloculatus & Crustacea Mysida & 1536 & 1750 & 1672.4 & 20.0 & 8.3 \\
\hline Pcar & Pheronema carpenteri & Porifera Hexactinellida & 847 & 1470 & 1465.6 & 58.1 & 4.2 \\
\hline Phyl & Phyllodocidae undet. & Annelida Polychaeta & 783 & 887 & 838.2 & 9.7 & 8.3 \\
\hline Plac & Placogorgia sp. & Cnidaria Anthozoa & 765 & 875 & 803.5 & 10.3 & 8.3 \\
\hline Pmar & Plesionika martia & Crustacea Decapoda & 749 & 928 & 759.9 & 16.7 & 33.3 \\
\hline Pden & Plinthaster dentatus & Echinodermata Asteroidea & 791 & 1809 & 1591.6 & 95.0 & 37.5 \\
\hline Podo & Podospongia sp. & Porifera Demospongia & 749 & 1750 & 771.5 & 93.4 & 6.3 \\
\hline Plae & Polycheles laevis & Crustacea Decapoda & 1536 & 1750 & 1716.2 & 20.0 & 18.8 \\
\hline Ptyp & Polycheles typhlops & Crustacea Decapoda & 737 & 1041 & 783.4 & 28.4 & 50.0 \\
\hline Pluc & Propeamussium lucidum & Mollusca Bivalvia & 1536 & 1686 & 1611.2 & 14.0 & 6.3 \\
\hline Pand & Psilaster andromeda & Echinodermata Asteroidea & 835 & 1809 & 1705.3 & 90.9 & 6.3 \\
\hline Role & Ranella olearium & Mollusca Gastropoda & 764 & 835 & 778.0 & 6.6 & 12.5 \\
\hline Rter & Rhinoclama teres & Mollusca Bivalvia & 1640 & 1750 & 1642.0 & 10.3 & 6.3 \\
\hline Spun & Scaphander punctostriatus & Mollusca Gastropoda & 1686 & 1750 & 1725.7 & 6.0 & 6.3 \\
\hline Schi & Schizopathes sp & Cnidaria Anthozoa & 887 & 1686 & 1409.3 & 74.5 & 6.3 \\
\hline Sgay & Sertularella gayi & Cnidaria Hydrozoa & 765 & 866 & 789.1 & 9.4 & 10.4 \\
\hline Sipu & Sipunculidae undet. & Sipunculida & 749 & 1750 & 1655.9 & 93.4 & 18.8 \\
\hline Sgus & Spondylus gussonii & Mollusca Bivalvia & 765 & 887 & 817.5 & 11.4 & 14.6 \\
\hline Steg & Stegopoma sp. & Cnidaria Hydrozoa & 765 & 866 & 790.6 & 9.4 & 8.3 \\
\hline Scra & Stephanocyathus crassus & Cnidaria Anthozoa & 737 & 1750 & 1640.9 & 94.5 & 27.1 \\
\hline Snan & Stereomastis nana & Crustacea Decapoda & 1640 & 1750 & 1714.9 & 10.3 & 12.5 \\
\hline Sscu & Stereomastis sculpta & Crustacea Decapoda & 875 & 1640 & 1476.0 & 71.4 & 6.3 \\
\hline Sros & Stichastrella rosea & Echinodermata Asteroidea & 765 & 1092 & 847.3 & 30.5 & 27.1 \\
\hline Styl & Stylasteridae undet. & Cnidaria Hydrozoa & 770 & 887 & 796.2 & 10.9 & 10.4 \\
\hline Sros & Swiftia rosea & Cnidaria Anthozoa & 765 & 1750 & 1527.6 & 91.9 & 54.2 \\
\hline Syll & Syllidae undet. & Annelida Polychaeta & 875 & 887 & 882.5 & 1.1 & 6.3 \\
\hline Sdeb & Systellaspis debilis & Crustacea Decapoda & 737 & 1750 & 1057.0 & 94.5 & 81.3 \\
\hline Tere & Terebellidae undet. & Annelida Polychaeta & 766 & 1092 & 792.3 & 30.4 & 12.5 \\
\hline Tmur & Thenea muricata & Porifera Demospongia & 749 & 1187 & 818.0 & 40.9 & 31.3 \\
\hline Triso & Trisopathes sp & Cnidaria Anthozoa & 851 & 1809 & 902.3 & 89.4 & 8.3 \\
\hline Tber & Troschelia berniciensis & Mollusca Gastropoda & 737 & 1750 & 1570.6 & 94.5 & 12.5 \\
\hline Umbe & Umbellula sp. & Cnidaria Anthozoa & 1470 & 1723 & 1701.7 & 23.6 & 12.5 \\
\hline Ucon & Uropyichus concolor & Crustacea Decapoda & 1460 & 1686 & 1520.3 & 21.1 & 10.4 \\
\hline Urub & Uroptychus rubrovittatus & Crustacea Decapoda & 770 & 847 & 787.2 & 7.2 & 18.8 \\
\hline Vermi & Vermiliopsis sp. & Annelida Polychaeta & 766 & 978 & 828.8 & 19.8 & 20.8 \\
\hline
\end{tabular}

\section{References}

Ambar, I., Howe, M.R., 1979. Observations of the Mediterranean outflow - I: mixing in the Mediterranean outflow. Deep-Sea Res. Part A 26, 535-554.
Auster, P.J., Moore, J., Heinonen, K.B., Watling, L., 2005. A habitat classification scheme for seamount landscapes: assessing the functional role of deep-water corals as fish habitat. In: Freiwald, A., Roberts, J.M. (Eds.), Cold-water Corals and Ecosystems. SpringerVerlag, Berlin Heidelberg, pp. 761-769. 
Bertrand, J., Gil de Sola, L., Papaconstantinou, C., Relini, G., Souplet, A., 2002. The general specifications of the MEDITS surveys. Sci. Mar. 66 (2), 9-17.

Black, M., Hill, M.N., Laughton, A.S., Matthews, D.H., 1964. Three non-magnetic seamounts off the Iberian coast. Q. J. Geol. Soc. Lond. 120 (1-4), 477-513.

Boehlert, G.W., Genin, A., 1987. A review of the effects of seamounts on biological processes. In: Keating, B.H., et al. (Eds.), Seamounts, Islands, and Atolls. Geophys. Monogr. Ser. vol. 43. AGU, Washington, D. C., pp. 319-334 (43).

Buchanan, J.B., 1984. Sediment analysis. In: Holme, N.A., McIntyre, A.D. (Eds.), Methods for the Study of Marine Benthos. Blackwell Scientific Publications, Oxford, pp. 41-65.

Buhl-Mortensen, L., Vanreusel, A., Gooday, A.J., Levin, L.A., Priede, I.G., Buhl-Mortensen, P., Gheerardyn, H., King, N.J., Raes, M., 2010. Biological structures as a source of habitat heterogeneity and biodiversity on the deep ocean margins. Mar. Ecol. 31, 21-50.

Cartes, J.E., 1993. Deep-sea decapods fauna of the western Mediterranean: bathymetric distribution and biogeographic aspects. Crustaceana 65 (1), 29-40.

Cartes, J.E., 1998. Feeding strategies and partition of food resources in deep-water decapod crustaceans (400-2300 m). J. Mar. Biol. Assoc. U. K. 78, 509-524.

Cartes, J.E., Abelló, P., 1992. Comparative feeding habits of polychelid lobsters in the western Mediterranean deep-sea communities. Mar. Ecol. Prog. Ser. 84, 139-150.

Cartes, J.E., Madurell, T., Fanelli, E., López-Jurado, J.L., 2008. Dynamics of suprabenthoszooplankton communities around the Balearic Islands (western Mediterranean): influence of environmental variables and effects on the biological cycle of Aristeus antennatus. J. Mar. Syst. 71, 316-335.

Cartes, J.E., Maynou, F., Fanelli, E., Romano, C., Mamouridis, V., Fanelli, E., 2009. The distribution of megabenthic, invertebrate epifauna in the Balearic Basin (western Mediterranean) between 400 and $2300 \mathrm{~m}$ : environmental gradients influencing assemblages composition and biomass trends. J. Sea Res. 61, 244-257.

Cartes, J.E., Mamouridis, V., Fanelli, E., 2011. Deep-sea suprabenthos assemblages (Crustacea) off the Balearic Islands (western Mediterranean): Mesoscale variability in diversity and production. J. Sea Res. 65, 340-354.

Cartes, J.E., Papiol, V., Frutos, I., Macpherson, E., González-Pola, C., Punzón, A., Valeiras, X., Serrano, A., 2014. Distribution and biogeographic trends of decapod assemblages from Galicia Bank (NE Atlantic) at depths between 700 and $1800 \mathrm{~m}$, with connexions to regional water masses. Deep-Sea Res., Pt II 106:165-178. http://dx.doi.org/10. 1016/j.dsr2.2013.09.034.

Cherbonnier, G., Sibuet, M., 1972. Résultats scientifiques de la campagne Noratlante: Astérides et Ophiurides. Bull. Mus. Nat. Hist. Nat. 76, 1333-1394.

Clarke, K.R., Warwick, R.M., 2001. Changes in Marine Communities, an Approach to Statistical Analysis and Interpretation. second ed. PRIMER-E, Plymouth.

Du Preez, C., Curtis, J.M.R., Clarke, M.E., 2016. The structure and distribution of benthic communities on a shallow seamount (Cobb Seamount, Northeast Pacific Ocean). PLoS One 11 (10), e0165513.

Duineveld, G.C.A., Lavaleye, M.S.S., Berghuis, E.M., 2004. Particle flux and food supply to a seamount coldwater coral community (Galicia Bank, NW Spain). Mar. Ecol. Prog. Ser. 277, 13-23.

Fanelli, E., Papiol, V., Cartes, J.E., 2011. Food web structure of deep-sea macrozooplankton and micronekton off the Catalan slope: insight from stable isotopes. J. Mar. Syst. 87 (1), 79-89.

Flach, E., Muthumbi, A., Heip, C., 2002. Meiofauna and macrofauna community structure in relation to sediment composition at the Iberian margin compared to the Goban Spur (NE Atlantic). Prog. Oceanogr. 52, 433-457.

Gage, J.D., 1983. Growth and production of Ophiocten gracilis (Ophiuroidea: Echinodermata) on the Scottish continental slope. Mar. Biol. 143 (85):97. http://dx doi.org/10.1007/s00227-003-1050-7.

Gage, J.D., 1986. The benthic fauna of the Rockall trough: regional distribution and bathymetric zonation. Proc. Roy. Soc. Edinb. 88B, 159-174.

Gage, J., Pearson, M., Clark, A.P.L., Tyler, P., 1983. Echinoderms of the Rockall trough and adjacent areas. I. Crinoidea, Asteroidea and Ophiuroidea. Bull. Br. Mus. Nat. Hist. (Zool.) 45 (5), 263-308.

Gage, J.D., Lamont, P.A., Kroeger, K., Paterson, G.L.J., González-Vecino, J.L., 2000. Patterns in deep-sea macrobenthos at the continental margin: standing crop, diversity and faunal change on the continental slope off Scotland. Hydrobiologia 440, 261-271.

Gallagher, M.L., Ambrose Jr., W.G., Renaud, P.E., 1998. Comparative studies in biochemical composition of benthic invertebrates (bivalves, ophiuroids) from the Northeast Water (NEW) Polynya. Polar Biol. 19, 167-171.

Genin, A., Dayton, P.K., Lonsdale, P.F., Spiess, F.N., 1986. Corals on seamount peaks provide evidence of current acceleration over deep-sea topography. Nature 322 (6074), 59-61.

Gofas, S., 2007. Rissoidae (Mollusca: Gastropoda) from the Northeast Atlantic seamounts. J. Nat. Hist. 41, 779-885.

Gubbay, S., 2003. Seamount of the North-East Atlantic. (OASIS report). (Hamburg and WWF Germany, Frankfurt am Main). pp. 1-38.

Henry, L.A., Roberts, J.M., 2007. Biodiversity and ecological composition of macrobenthos on cold-water coral mounds and adjacent off-mound habitat in the bathyal Porcupine Seabight, NE Atlantic. Deep-Sea Res. I 54, 654-672.

Hessler, R.R., Jumars, P.A., 1974. Abyssal community analysis from replicate box cores in the central North Pacific. Deep-Sea Res. 21 (3):185-209. http://dx.doi.org/10.1016/ 0011-7471(74)90058-8.

Howell, K.L., 2010. A benthic classification system to aid in the implementation of marine protected area networks in the deep/high seas of the NE Atlantic. Biol. Conserv. 143, 1041-1056.

Howell, K.L., Billett, D.S.M., Tyler, P.A., 2002. Depth-related distribution and abundance of seastars (Echinodermata: Asteroidea) in the Porcupine Seabight and Porcupine Abyssal Plain, N.E. Atlantic. Deep-Sea Res. Pt. I 49, 1901-1920.
Howell, K.L., Davies, J.D.S., Narayanaswamy, B.E., 2010. Identifying deep-sea megafaunal epibenthic assemblages for use in habitat mapping and marine protected area network design. J. Mar. Biol. Assoc. UK 90 (1), 33-68.

Hudson, I.R., Pond, D.W., Billett, D.S.M., Tyler, P.A., Limpitt, R.S., Wolff, G.A., 2004. Temporal variations in fatty acid composition of deep-sea holothurians: evidence of benthopelagic coupling. Mar. Ecol. Prog. Ser. 281, 109-120.

Iorga, M.C., Lozier, M.S., 1999. Signatures of the Mediterranean outflow from a North Atlantic climatology 2. Diagnostic velocity fields. J. Geophys. Res. 104, 25.985-26.009.

Lamont, P.A., Gage, J.D., 1998. Dense brittle star populations on the Scottish continental slope. In: Mooi, R., Telford, M. (Eds.), Proceed. Ninth Inter. Echinoderms Confer. 1996, pp. 377-382 (San Francisco, California, USA).

Loo, L.O., Jonsson, P.R., Sköld, M., Karlsson, O., 1996. Passive suspension feeding in Amphiura filiformis (Echinodermata: Ophiuroidea): feeding behaviour in flume flow and potential feeding rate of field populations. Mar. Ecol. Prog. Ser. 139, 143-155.

McClain, C.R., Lundsten, L., 2014. Assemblage structure is related to slope and depth on a deep offshore Pacific seamount chain. Mar. Ecol. 36 (82), 210-220.

Metaxas, A., Giffin, B., 2004. Dense beds of the ophiuroid, Ophiacantha abyssicola, on the continental slope of Nova Scotia, Canada. Deep-Sea Res. Pt I 51, 1307-1317.

Moore, D.R., Bullis, H.R., 1960. A deep-water coral reef in the Gulf of Mexico. Bull. Mar. Sci. $10(1), 125-128$

Olabarria, C., 2005. Patterns of bathymetric zonation of bivalves in the Porcupine Seabight and adjacent abyssal plain, NE Atlantic. Deep-Sea Res. Pt I 52, 15-31.

OSPAR Commision, 2008. List of Threatened and/or Declining Species and Habitats. (Reference Number: 2008-6). OSPAR Secretariat, London.

Papiol, V., Cartes, J.E., Serrano, A., Frutos, I., Preciado, I., González-Pola, C., Sánchez, F. 2014. Structure of the Community of Deep-water Near-bottom Macroplankton and Micronekton From the Galicia Bank (NE Atlantic) and Relationships With Environmental Drivers. Proceed. XIV Inter. Symp.ISOBAY, p. 58.

Preciado, I., Cartes, J.E., Punzón, A., Frutos, I., López-López, L., Serrano, A., 2016. Food web functioning of the benthopelagic community in a deep-sea seamount based on die and stable isotope analyses. Deep Sea Res., Part II. http://dx.doi.org/10.1016/j.dsr2. 2016.07.013.

Prieto, E., González-Pola, C., Lavín, A., Sánchez, R.F., Ruiz-Villarreal, M., 2013. Seasonality of intermediate waters hydrography west of the Iberian Peninsula from an $8 \mathrm{yr}$ semiannual time series of an oceanographic section. Ocean Sci. 9:411-429. http://dx.doi. org/10.5194/os-9-411-2013.

Rogers, A.D., 1994. The biology of seamounts. Adv. Mar. Biol. 30:305-350. http://dx.doi org/10.1016/S0065-2881(08)60065-6

Rowden, A.A., Schlacher, T.A., Williams, A., Clark, M.R., Stewart, R., Althaus, F., Bowden, D.A., Consalvey, M., Robinson, W., Dowdney, J., 2010. A test of the seamount oasis hypothesis: seamounts support higher epibenthic megafaunal biomass than adjacent slopes. Mar. Ecol. 31 (Suppl. 1):95-106. http://dx.doi.org/10.1111/j.1439-0485. 2010.00369.x.

Samadi, S., Schlacher, T., de Forges, B.R., 2007. Seamount benthos. In: Pitcher, T.J., Morato T., Hart, P.J.B., Clark, M.R., Haggan, N., Serrão Santos, R. (Eds.), Seamounts: Ecology, Fisheries and Conservation. Blackwell Publishing, pp. 119-140 (Chapt. 7).

Sánchez, F., González-Pola, C., Druet, M., García-Alegre, A., Acosta, J., Cristobo, J., Parra, S. Ríos, P., Altuna, A., Gómez-Ballesteros, M., Muñoz, A., Rivera, J., Díaz del Río, G., 2014 Habitat characterization of deep-water coral reefs in La Gaviera Canyon (Avilés Canyon System, Cantabrian Sea). Deep-Sea Res. Pt II 106, 118-140.

Schlacher, T.A., Baco, A.R., Rowden, A.A., O'Hara, T.D., Clark, M.R., Kelley, C., Dower, J.F., 2013. Seamount benthos in a cobalt-rich crust region of the Central Pacific: conservation challenges for future seabed mining. Divers. Distrib. 20 (5), 491-502.

Somoza, L., Ercilla, G., Urgorri, V., León, R., Medialdea, T., Paredes, M., González, F.J. Nombela, M.A., 2014. Detection and mapping of cold-water coral mounds and living Lophelia reefs in the Galicia Bank, Atlantic NW Iberia margin. Mar. Geol. 349, 73-90,

Stefanescu, C., Lloris, D., Rucabado, J., 1992. Deep-living demersal fishes in the Catalan Sea (western Mediterranean), below a depth of 1000 m. J. Nat. Hist. 26, 197-213.

Surugiu, V., Dauvin, J.C., Gillet, P., Ruellet, T., 2008. Can seamounts provide a good habitat for polychaete annelids? Example of the northeastern Atlantic seamounts. Deep-Sea Res., Pt. I 55, 1515-1531.

Tempera, F., Giacomello, E., Mitchell, N.C., Campos, A.S., Braga Henriques, A., Bashmachnikov, I., Martins, A., Mendonça, A., Morato, T., Colaço, A., Porteiro, F.M. Catarino, D., Gonçalves, J., Pinho, M.R., Isidro, E.J., Santos, R.S., Menezes, G., 2012. Mapping condor seamount seafloor environment and associated biological assemblages (Azores, NE Atlantic). In: Harris, Peter T., Baker, Elaine K. (Eds.), Seafloor Geomorphology as Benthic Habitat- Geohab Atlas of Seafloor Geomorphic features and benthic habitats. Elsevier, pp. 807-817 (Chapter 59).

Tendal, O.S., 1992. The North Atlantic distribution of the octocoral Paragorgia arborea (L, 1758) (Cnidaria, Anthozoa). Sarsia 77 (3-4):213-217. http://dx.doi.org/10.1080 00364827.1992 .10413506$.

Ter Braak, C.J.F., Smilauer, P., 2002. CANOCO Reference Manual and CanoDraw for Windows User's Guide: Software for Canonical Community Ordination (Version 4.5). Microcomputer Power, Itaca.

Thatje, S., 2004. Reproductive trade-offs in benthic decapod crustaceans of high southern latitudes: tolerance of cold and food limitation. Ber Polarforsch Meeresforsch (Rep. Polar. Mar. Res.) 483, 1-183.

Verdonschot, P.F.M., Ter Braak, C.J.F., 1994. An experimental manipulation of oligochaete communities in mesocosms treated with chlorophytos or nutrient additions: multivariate analyses with Monte Carlo permutation tests. Hydrobiologica 278, 251-266. 